\title{
Sustainable management of diseases and pests in crops by vermicompost and vermicompost tea. A review
}

\author{
Ali Mohd Yatoo ${ }^{1,2} \cdot$ Md. Niamat Ali ${ }^{2} \cdot$ Zahoor Ahmad Baba $^{3} \cdot$ Birjees Hassan ${ }^{1}$ \\ Accepted: 19 November 2020 / Published online: 7 January 2021 \\ (C) INRAE and Springer-Verlag France SAS, part of Springer Nature 2021
}

\begin{abstract}
The intensive use of inorganic fertilizers and pesticides in the agricultural field has globally destroyed soil fertility, killed beneficial microorganisms, and also decreased natural resistance in crops, thereby making them more vulnerable to diseases besides affecting human health and the environment. To overcome these problems, it is very important to shift our attention towards eco-friendly alternatives like vermicompost and vermicompost tea which not only can increase crop growth and yield, suppress diseases and pests sustainably but can also protect human health and the environment. Vermicompost with its rich nutrient content, plant growth promoters like auxins, gibberellins, cytokinins, and beneficial microbes not only improves the growth and yield of crops but also increases the diversity and activity of antagonistic microbes and nematodes, which helps to suppress pests and diseases caused by soil-borne phytopathogens. Vermicompost tea also has a tremendous potential to protect plants from diseases and its application to plants can coat leaf surfaces and reduce available sites for pathogen infection or increases microbial diversity that can kill harmful pathogens. Here, we review recent scientific achievements towards the management of crop diseases and pests by these organic amendments and the major points are the following: (1) production of vermicompost and vermicompost tea, (2) management of crop pests and diseases by vermicompost and vermicompost tea, and (3) the possible mechanisms and some important factors involved in the suppression of diseases and pests. Finally, we conclude that by using these eco-friendly organic amendments as a replacement to inorganic pesticides and fungicides, diseases and pests can be managed successfully without affecting human health and the environment and chemical-free food can be provided to humankind in the future.
\end{abstract}

Keywords Vermicompost - Vermicompost tea - Sustainable disease management · Pest control mechanism · Food security · Competition

\section{Contents}

Ali Mohd Yatoo

aliyatoo123@gmail.com

Md. Niamat Ali

mdniamat@hotmail.com

1 Centre of Research for Development/Department of Environmental Science, University of Kashmir, Srinagar, Jammu and Kashmir, India

2 Cytogenetics and Molecular Biology Laboratory/ Centre of Research for Development, University of Kashmir, Srinagar, Jammu and Kashmir, India

3 Biofertilizer Research Laboratory, Division of Basic and Humanities, Wadoora, Sher-e-Kashmir University of Agricultural Science and Technology, FOA, Sopore, Jammu and Kashmir, India

1. Introduction

2. Vermicompost and its production

3. Vermicompost tea and its production

4. Superiority of vermicompost over compost

4.1 Produced in shorter time

4.2 More nutritious

4.3 Less electrical conductivity and phytotoxicity

4.4 More microbes

4.5 More phytohormones

4.6 More mature and stable

4.7 Less heavy metals

4.8 Less pathogens

4.9 Higher disease suppression

4.10 Enhanced growth and yield of crops

5. Disease and pest control by vermicompost 


\subsection{Disease suppression}

5.2 Pest control

6. Disease and pest control by vermicompost tea

6.1 Disease suppression

6.2 Pest control

7. Mechanism of disease suppression by vermicompost and vermicompost tea

7.1 General suppression mechanism

\subsubsection{Competition}

7.1.2 Antibiosis

7.1.3 Hyperparasitism/Predation

7.1.4 Induced systemic resistance

7.2 Specific suppression mechanism

8. Mechanism of pest control by vermicompost and vermicompost tea

8.1 Release of phenolic substances

8.2 Increase in number of predatory nematodes and beneficial microbes

8.3 Release of some toxic substances

8.4 Overall increase in nutrient availability

9. Factors affecting disease and pest suppressive ability of vermicompost and vermicompost tea

9.1 Compost source, quality and maturity

9.2 Compost to water ratio

9.3 Brewing time

9.4 Nutrient supplements

9.5 Aeration

9.6 Dilution and application factors

9.7 Microbial supplements

10. Conclusion

Acknowledgments

References

\section{Introduction}

The population of the world is growing at a fast speed, especially in developing countries. In order to meet the load of an ever-increasing human population, worldwide agricultural production is required to get doubled by 2050 ; however, present estimates are less than what is required (Ray et al. 2013). The production of crops is decreased by $36 \%$ worldwide by plant diseases, weeds, and insects, and diseases alone have been reported to decrease crop yield by 14 percent (Agrios 2005). On the other hand, the application of chemicals against such diseases mostly gives good results. However, the misuse of these inorganic substances has been an issue of public concern as they have destroyed the natural fertility of soil, killed beneficial soil organisms, reduced the natural resistance ability in crops, and also led to environmental pollution (Adhikary 2012; Keswani et al. 2014; Bisen et al. 2015). Several authors have also reported that certain pesticides, even at their recommended doses, are harmful to other beneficial species (Abida et al. 2000; Nasreen et al. 2003), and when sprayed, some part may remain in the agricultural land while some may enter the surrounding water, air, and soil (Malone et al. 2004; Lefrancq et al. 2013).Therefore, to overcome these problems, it is imperative to apply biological control like vermicompost and vermicompost tea as a safe and efficient alternative against such diseases, which have been considered important in the last few years for the control of many soil-borne phytopathogens (Abada and Ahmed 2014; Abada and Hassan 2017; Ragab Mona et al. 2015; Devi and Das 2016). In organic farming, they play a very vital role in increasing the fertility of soil, nourishment of crops and fighting against diseases (Fig. 1). The application of compost and vermicompost as soil fertilizers helps in preserving, restoring soil fertility (Kumar et al. 2013; Passarini et al. 2014) as well as enhancing soil biodiversity by substantially improving microbial biomass (Hernandez et al. 2014). Their application also plays a significant role towards sustainability in the agriculture production (De corato 2020). The occurrence of a broad variety of antagonistic microbes in vermicast ensures the efficient biocontrol of soil borne phyto-pathogenic fungi (Singh et al. 2008; Pathma and Sakthivel 2012). A number of studies have reported that due to the presence of actinomycetes and antibiotics, the application of vermicompost repels crop pests, suppresses infection caused by insects, and also induces biological resistance in plants against diseases and pests (Munroe 2007). While other workers have found that nutrients present in vermicompost are available in plant accessible forms like phosphates, nitrates, soluble calcium, and potassium (Jangra et al. 2019) besides containing plant growth regulators as well as beneficial microorganisms especially bacteria, fungi, and actinomycetes which makes it more appropriate and suitable for the overall growth and production of plant (Joshi et al. 2015)

In addition to solid form, the liquid solution of vermicompost, i.e., vermicompost tea, has also been extensively used (Zaller 2006; Edwards et al. 2009) for the management of plant diseases and pests since the last two decades (SimsekErsahin et al. 2009).Vermicompost tea, known as organic biofertilizer, contains microbes, nutrients, and plant growth promoters, and its application has shown an improvement in seed germination, growth and yield enhancement, and plant disease suppression (Khattiyaphutthimet et al. 2020; Arancon et al. 2020). Both solid and liquid forms of vermicompost have very high potential for the production and protection of crops. It is believed that nutrients and microbes get transferred from vermicast into liquid solution, commonly known as vermicompost tea, rendering it more applicable (Ingham 2005; Pant et al. 2009). Vermicompost teas also have significant potential for pest control because of the presence of phenolic substances that makes the plant tissues unpalatable (Pathma and Sakthivel 2012). Commercially as an organic fertilizer, compost tea is applied for the growth and yield of vegetables as well as to 
suppress several diseases as substitutive control (Martin and Brathwaite 2012; Kim et al. 2015). Thus, these organic solutions are considered to be potent alternatives to chemical pesticides and fungicides and should be applied more and more so that diseases, as well as food security and safety, can be ensured

\section{Vermicompost and its production}

Vermicompost is derived from organic wastes with the help of earthworms (Edwards and Arancon 2004a; Blouin et al. 2019) having high water retaining potential, microbial action, and nutrient concentration (Edwards 2004; Pandya et al. 2014; Soobhany et al. 2017a). In recent years, vermicompost has received increased attention due to its remarkable physicochemical and biological features (Huang et al. 2014). Physically, vermicompost-amended soils have better aeration, porosity, structure (Zhu et al. 2017), and chemical parameters like $\mathrm{pH}$, conductivity, organic matter and nutrient status enhanced considerably and led to improved crop growth and yield due to vermicompost application (Lim et al. 2015). Vermicompost is considered a long-term source of both micro- and macro-nutrients which are assimilated by crops very easily Atiyeh et al. 2000a). In addition to these, there is also presence of nitrogen fixing and phosphorus-solubilizing bacteria (Yatoo et al. 2020), substances like gibberellins, auxins, cytokinins, vitamins, humic acids, and defensive enzymes (Ravindran et al. 2016; Amooaghaie and Golmohammadi 2017) in vermicast which encourage the overall growth, development, and productivity of crops (Fig. 2) (Atiyeh et al. 2002a; Olle 2016; Adiloğlu et al. 2018). Furthermore, for the fertility improvement, nutrient pool enhancement, and water conservation in soil, vermicompost application has been observed to be an efficient way (Makode 2015). A broad range of indirect effects has also been shown by vermicompost on growth of plants such as control or

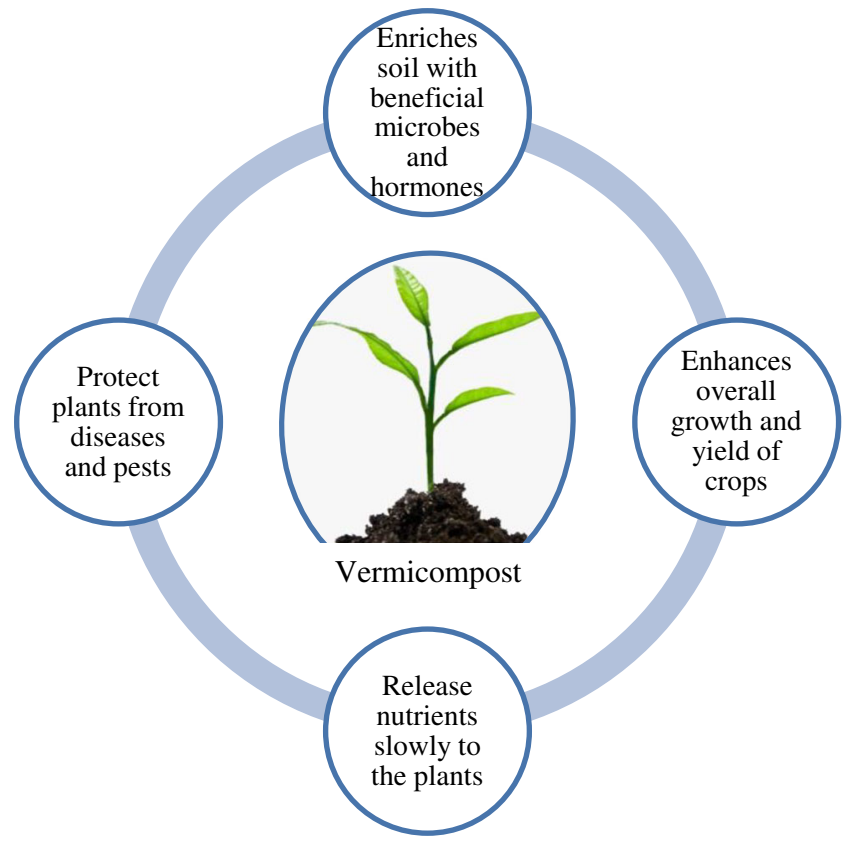

Fig. 2 The addition of vermicompost to crops enriches the soil with beneficial plant growth hormones, essential nutrients, and beneficial microbes that suppress the diseases and pests and enhance the overall growth and productivity of crops

suppression of pests, parasitic nematodes, and diseases (Singh et al. 2008; Basco et al. 2017). At present, vermicompost is well-known for its ability to produce a good yield of crops and has been extensively utilized for the cultivation of maize (Kmet'ová and Kováčik 2014), wheat (Yousefi and Sadeghi 2014), peppermint (Ayyobi et al. 2014), tomatoes (Zucco et al. 2015), capsicum (Rekha et al. 2018), and garlic (Gichaba et al. 2020). The vermicompost application provided similar results as that of chemical fertilizers (Singh et al. 2008; Ghasem et al. 2014), whereas other authors have reported that vermicompost outperformed chemical fertilizers in terms of yield enhancement and pest and
Fig. 1 Vermicompost improves growth and reduces disease in crops. The right side pot shows higher growth and no disease symptoms in the tomato plant which was due to the addition of vermicompost, while the left side pot containing soil only (no vermicompost) shows reduced growth and disease symptoms
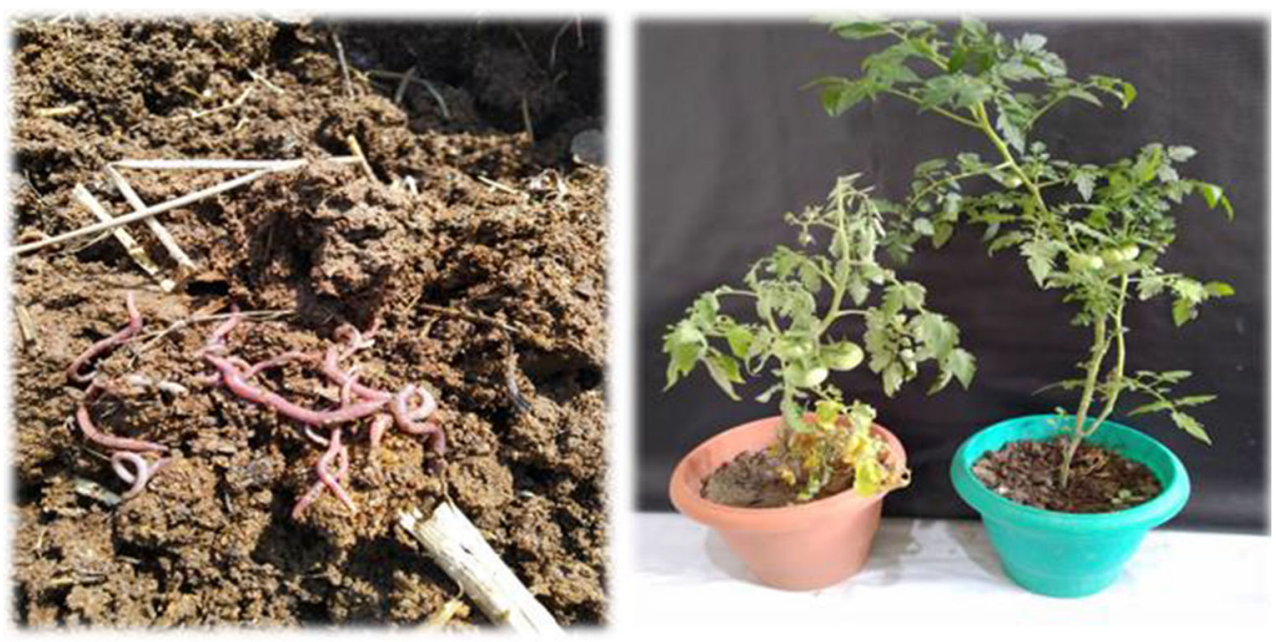
disease management (Mahmud et al. 2018; Ganeshnauth et al. 2018) therefore making vermicompost as a good substitute to replace inorganic fertilizers (Yatoo et al. 2020). A cost analysis of vermicompost and chemical fertilizer was carried out and it was observed that overall costs (fertilizer and labor) were lower in vermicompost grown plants relative to chemical-grown plants (Mahmud et al. 2018).

\section{Vermicompost tea and its production}

Vermicompost tea is the liquid solution of vermicompost and it is derived by mixing vermicast with water and fermenting it for a particular period of time (Edwards et al. 2007; NOSB 2004). It is categorized into two types: aerated and nonaerated compost tea. During the process of steeping compost in water, nutrients and microorganisms get extracted. The presence of microorganisms converts insoluble nutrients into soluble forms and these available nutrients in turn promote vast diversity of organisms in vermicompost tea during its brewing process. Both methods of producing vermicompost tea (aerated and non-aerated) involve brewing matured compost in water for a particular period of time and need filtration before application to plants. Irrespective of the brewing method used, de-chlorination of water is very important in order to enhance the growth and multiplication of microbes, as growth and propagation can be inhibited by the presence of chlorine and chloramines. This can be simply achieved by keeping tap water to stand overnight in the brewing container (Allen 1994) or by aerating it for 20 to $120 \mathrm{~min}$ (Allen 1994; Martin et al. 2012). Aerated tea is made by providing aeration to wellmatured compost suspending in water for about 12 to $24 \mathrm{~h}$. Besides active aeration and compost source, the final biochemical characteristic of vermicompost tea often depends upon number of factors and is often supplemented with nutrients, microbial inoculants, and oxygen to enhance its biological activity (Ingham 2005; Naidu et al. 2010), while as nonaerated tea is made by suspending compost or a bag of compost for 14 days in a bucket of water so that nutrients and anaerobic microorganisms are extracted which is then used to enhance growth and strength in crops (Naidu et al. 2010). The mode of action by compost tea for disease inhibition is not well-known (Scheuerell 2002). However, one theory is that the physico-chemical properties of nutrients and humic substances present in compost tea may improve nutritional content of plants, induce systematic resistance against the pathogen and /or be directly toxic to the plant pathogen (Kone' et al. 2010). Another theory is that the compost teas on the surface of leaves favor the growth of beneficial microbes, thereby acting as a biocontrol agent of pathogens (Dianez et al. 2007).

Both forms of vermicompost (vermicompost and vermicompost tea) have an enormous potential for the production and protection of crops. However, they are not as popular as inorganic fertilizers and pesticides because they are emerging areas developed recently after extensive analysis of compost and compost tea; farmers are less aware about the beneficial effects of these organic amendments, and they are not easily available in the market, etc. Therefore, in order to make them more popular among the farmers, their production needs to be increased, which can be achieved by conducting workshops on these organic amendments, providing the required knowledge to farmers, taking initiatives by the governments to convert organic portions of municipal waste into these value-added products, engaging unemployed youth (especially rural) to use vermitechnology to produce more and more vermicompost and in this way both their economy can be improved and sustainable agriculture can be promoted.

\section{Superiority of vermicompost over compost}

The use of organic fertilizers, like compost and vermicompost, is an effective way to enhance and preserve the soil organic matter, remediate depleted soil, and provide the beneficial nutrients that are essential for the plants (Mylavarapu and Zinati 2009; Amiri et al. 2017). Compost or vermicompost produced from various organic wastes is an essential agricultural supplement because of their beneficial effects on diverse properties of soil (Zandvakili et al. 2019). These organic amendments are reported to enhance the growth of plants by providing essential nutrients, improving beneficial microorganisms, and managing harmful pests and diseases (StewartWade 2020), and may have a long-term effect on agroecosystem productivity and sustainability (Mas-Carrió et al. 2018; Domínguez et al. 2019). Both composts and vermicomposts are used for the growth and development of crops; however, due to some negative aspects of compost such as higher electrical conductivity, existence of more pathogens, low nutrient concentrations, and higher phytotoxicity (GarcíaGómez et al. 2002; Bloem et al. 2017; Joshi et al. 2020), vermicompost is preferred for plant growth by most of the consumers. As an organic fertilizer and a bio-control agent, vermicompost has been shown to be more effective with respect to its counterpart, compost (Edwards and Arancon 2004b). A meta-analysis has shown that adding vermicompost to soil on an average enhances commercial crop production by $26 \%$, overall biomass by $13 \%$, root and shoot biomass by 57 and $78 \%$, respectively (Blouin et al. 2019).Vermicompost can enhance growth and yield of any agricultural crop, including horticultural crops like tomato (Ravindran et al. 2019; Aslam et al. 2020), Brinjal (Samadhiya et al. 2014), pepper (Arancon et al. 2005), Green bean (Soobhany et al. 2017a), garlic (Argüello et al. 2006), Ladies finger (Hussain et al. 2017), aromatic herbs (Islam et al. 2016a; El-Haddad et al. 2020) medicinal plants (Singh and Mallick 2020), cereals like rice 
(Bhattacharjee et al. 2001), Wheat (Erdal and Ekinci 2020), Maize (Doan et al. 2015), fruit crops like banana (CabanasEchevarría et al. 2005) papaya (Acevedo and Pire 2004), pineapple (Mahmud et al. 2018), and ornamental plants (Atiyeh et al. 2002b; Belda et al. 2013). Likewise, vermicompost tea can be used to promote the growth and development of crops like tomato (Tejada et al. 2008; Aslam et al. 2020), bell pepper (dos Santos et al. 2020), Maize (Aslam and Ahmad 2020), and strawberries (Singh et al. 2010). However, vermicompost products are mostly used in growing horticultural crops. As vermicompost can be applied to any agricultural crop, the same can also be produced from any type of organic waste like municipal waste (Soobhany et al. 2017b), tannery waste (Ravindran et al. 2019), agricultural waste (Kamalraj et al. 2017), horticultural waste (Mendoza-Hernández et al. 2014), animal manure (Szczech and Smolinska 2001), poultry waste (Joshi et al. 2020), and aquatic waste (Hussain et al. 2017). However, it has been reported that cow dung is the best organic waste to produce vermicompost (Blouin et al. 2019). A comparative analysis of vermicompost and vermicompost tea produced from different organic wastes using the same earthworm species was conducted by Zarei et al. (2018) and reported that cow manure vermicompost and vermicompost tea contain higher macro- and micro-nutrients compared to leaf meal vermicompost and vermicompost tea. Several other authors also claimed that the final quality depends on the nature of the raw material, the type of earthworm used, and the environmental conditions prevailing (Tognetti et al. 2005; Ganiger et al. 2020).

Compared to traditional compost, vermicompost is often marked as having superior quality with respect to nutrient concentration, higher microbial diversity, phytohormones etc. (Dominguez et al. 1997; Subler et al. 1998) (Table 1), and its addition to soil enhances crop growth (Kashem et al. 2015; Kaur et al. 2015). Some of the advantages of vermicompost over compost are discussed in the following sub-sections briefly.

\subsection{Produced in shorter time}

Vermicompost is produced by the combined action of earthworms and microbes (Benitez et al. 1999; Domínguez et al. 2019) whereas compost is produced only by the action of microbes (Litterick and Wood 2009; St. Martin and Brathwaite 2012). As compared to compost, vermicast is produced in a shorter time because of the presence of humic substances that enhances the process of humification, which intensifies the conversion of organic matter (Singh and Singh 2017), and also because earthworms host millions of degrading microorganisms, hydrolytic enzymes, and hormones that help to rapidly decompose complex organic waste into vermicast over a relatively shorter period of one to
2 months (Sanchez-Monedero et al. 2001) compared to conventional composting that takes almost 5 months (Munnoli et al. 2010).

\subsection{More nutritious}

Vermicompost contains higher concentration of both macroand micro-nutrients compared to composts. In the case of vermicompost, microbial populations are dominated by mesophilic bacteria and fungi that produce nitrogen as nitrate, a more suitable form for plants, compared to composting where thermophilic bacteria produce nitrogen as ammonia (Atiyeh et al. 2000b; Edwards and Arancon 2004b; Jayashree et al. 2008). A comparative study was performed on the conversion of the same material by composting and vermicomposting and it was reported that vermicompost contains significantly higher macronutrient concentrations compared to compost (Joshi et al. 2020). It was stated that the higher NPK content was due to the microbial activity present both within the gut of earthworms and in the earthworm cast. Suthar (2007) also indicated that an improvement in total nutrient concentration during sewage-sludge vermicomposting was due to enhanced microbial action, which subsequently increases the rate of mineralization and concentration of nutrients.

\subsection{Less EC and phytotoxicity}

The salinity of organic fertilizer is reflected by the electrical conductivity (EC). Higher salinity can cause phytotoxicity problems and thus EC is an excellent indicator that signifies whether the compost or vermicompost is safe and suitable for agricultural purposes or not. High EC means the high concentration of salt which, by enhancing the osmotic potential, restricts the accessibility of water to plants (Bunt 1988). Lazcano et al. (2008) indicated that when same organic waste was subjected to composting and vermicomposting, the compost contains higher EC compared to vermicompost. Several other researchers have also stated that the large quantities of soluble salts such as ammonium and phosphate are released during composting (Villar et al. 1993), while less ammonium is released during vermicomposting, leading to lower EC values (Mitchell 1997). Belda et al. (2013) reported that when tomato waste-based compost and vermicompost were tested on two ornamental plants, the vermicompost was much better than compost in terms of overall effect on plants. They further reported that compost was found to be phytotoxic, possibly due to higher electrical conductivity, which was evident from the reduction in seed germination and growth of both the plants. This is considered to be a very crucial and a significant limiting factor, especially in nursery development, as the early stages of plant growth are highly sensitive to the salinity of the growth media (Fornes et al. 2007). 
Table 1 Superiority of vermicompost over compost on the basis of few important parameters

\begin{tabular}{|c|c|c|c|c|c|}
\hline $\begin{array}{l}\text { S. } \\
\text { no }\end{array}$ & Parameter & Compost & Vermicompost & Key findings & References \\
\hline 1. & $\mathrm{C}: \mathrm{N}$ ratio & High $\mathrm{C}: \mathrm{N}$ ratio & Low $\mathrm{C}: \mathrm{N}$ ratio & $\begin{array}{l}\text { Vermicast has a low } \mathrm{C}: \mathrm{N} \text { ratio relative } \\
\text { to compost that may be attributed to the } \\
\text { respiratory activities of earthworms } \\
\text { and microbes and is thus more stable } \\
\text { and mature than compost. }\end{array}$ & $\begin{array}{l}\text { Ravindran et al. } \\
\quad(2015,2016)\end{array}$ \\
\hline 2. & Growth and yield & $\begin{array}{l}\text { Less root, shoot weight } \\
\text { and fruit yield of } \\
\text { green bean }\end{array}$ & $\begin{array}{l}\text { More root, shoot weight } \\
\text { and fruit yield of } \\
\text { green bean }\end{array}$ & $\begin{array}{l}\text { Because of higher macronutrients and } \\
\text { growth hormones, vermicompost } \\
\text { outperformed compost when used in } \\
\text { equal amounts. }\end{array}$ & $\begin{array}{l}\text { Soobhany et al. } \\
\text { (2017a) }\end{array}$ \\
\hline 3. & $\begin{array}{l}\text { NPK } \\
\left(\text { g kg }^{-1)}\right.\end{array}$ & $\begin{array}{l}\text { Low nutrient content } \\
\mathrm{N}(8.6), \mathrm{P}(4.8), \mathrm{K}(5.3)\end{array}$ & $\begin{array}{l}\text { High nutrient content } \\
\mathrm{N}(10.8), \mathrm{P}(7.0), \mathrm{K}(5.6)\end{array}$ & $\begin{array}{l}\text { Vermicompost contains significantly } \\
\text { higher nutrient concentrations compared } \\
\text { to compost and when added to soil } \\
\text { produced higher ryegrass yields. }\end{array}$ & Tognetti et al. (2005) \\
\hline 4. & $\mathrm{EC}$ & $\operatorname{High}\left(2.85 \mathrm{dS} \mathrm{m}^{-1}\right)$ & Low $\left(0.65 \mathrm{dS} \mathrm{m}^{-1}\right)$ & $\begin{array}{l}\text { Compost was phytotoxic, possibly due to } \\
\text { high EC, which was evident from a } \\
\text { reduction in seed germination, plant } \\
\text { growth and chlorophyll content. }\end{array}$ & Belda et al. (2013) \\
\hline 5. & Enzyme activities & $\begin{array}{l}\text { Delayed enzyme } \\
\text { activities }\end{array}$ & Faster enzyme activities & $\begin{array}{l}\text { Maximum enzyme activities like urease, } \\
\text { cellulase, protease etc. were found in } \\
\text { vermicompost during } 21-35 \text { days, } \\
\text { while in compost delayed enzyme } \\
\text { activities were observed on } 42-49 \text { days. }\end{array}$ & Devi et al. (2009) \\
\hline 6. & Bacterial diversity & Low & High & $\begin{array}{l}\text { Vermicomposting is the best process to } \\
\text { produce organic fertilizer with greater } \\
\text { bacterial number, diversity and } \\
\text { functional diversity. }\end{array}$ & Vivas et al. (2009) \\
\hline 7. & End product & $\begin{array}{l}\text { Good quality end } \\
\text { product }\end{array}$ & Better quality end product & $\begin{array}{l}\text { Vermicomposting is superior in } \\
\text { transforming } \\
\text { poultry waste into better end product } \\
\text { compared to composting, as vermicast } \\
\text { has higher NPK concentrations and a } \\
\text { lower C: N ratio. }\end{array}$ & Joshi et al. (2020) \\
\hline 8. & $\begin{array}{l}\text { Plant growth } \\
\text { hormones and } \\
\text { microbial } \\
\text { number }\end{array}$ & $\begin{array}{l}\text { Minimum growth } \\
\text { hormones and } \\
\text { microbial number }\end{array}$ & $\begin{array}{l}\text { Maximum growth } \\
\text { hormones and } \\
\text { microbial } \\
\text { number }\end{array}$ & $\begin{array}{l}\text { Maximum growth hormones and microbial } \\
\text { number were present in tannery waste } \\
\text { vermicompost compared to compost } \\
\text { which was possibly due to combined } \\
\text { action of earthworms and microbes. }\end{array}$ & $\begin{array}{l}\text { Ravindran et al. } \\
\text { (2016) }\end{array}$ \\
\hline
\end{tabular}

\subsection{More microbes}

Several scholars have stated that, compared with compost, vermicompost contains higher microbial number and diversity (Vivas et al. 2009; Anastasi et al. 2004). Conventional compost supports only selected microorganisms, whereas vermicompost is a rich source of microbial diversity and activity which acts as a powerful biocontrol agent in suppressing soil borne phytopathogens (Scheuerell et al. 2005; Jack et al. 2011). The existence of desirable microbes in vermicompost like fungi, bacteria, and actinomycetes may support plant growth by releasing enzymes and hormones that stimulate plant growth and thus indirectly suppress plant pests and diseases (Pathma and Sakthivel 2014). Earthworm castings are highly nutritious and rich in calcium humate which encourages the growth of useful microbes, such as Trichoderma sp. (Tiunov and Scheu 2000), Pseudomonas spp. (Schmidt et al.
1997) Azospirillum spp., Azotobacter spp., and Nitrobacter spp. (Gopal et al. 2009). Pathma and Sakthivel (2013) have also recorded a wide variety of microbes like Bacillus, Arthrobacter, Pseudomonas, and Acinetobacter in goat- and straw-based vermicompost, most of which displayed an antagonistic capacity against phytopathogens. Microbial diversity analysis of compost and vermicompost, produced from same material, was investigated and it was reported that the highest microbial count was observed in vermicompost, while in compost lowest count was observed. This improvement in vermicompost may be because of the favorable conditions for the growth of microbes in the digestive tract of worms and by the ingestion of nutritious organic waste which provides energy and acts as a substrate for the growth of microbes (Ravindran et al. 2016). Other authors reported that the unexpected lower microbial activities in compost might be due to the formation of anaerobic niches, leading to the production of 
gases such as methane and $\mathrm{N}$ oxide in beds that reduce the microbial populations (Joshi et al. 2020).

\subsection{More phytohormones}

An analysis was carried out by Ravindran et al. (2016) to turn tannery-based waste into useful finished product through composting and vermicomposting. They observed phytohormones in both compost and vermicompost; however, maximum phytohormones $(\mathrm{mg} / \mathrm{kg})$ were detected as Indole 3acetic acid (7.37), kinetin (2.8), and gibberellic acid (5.7) in vermicompost and minimum were recorded as IAA (5.84), kinetin (2.7), and GA (3.4) in compost. The results revealed that the maximum amount of phytohormones present in vermicompost was due to the mutual action of microbes and earthworms. Tomati et al. (1988) also recorded high value of hormones like auxins, cytokinins, and gibberellins in sewage sludge-based vermicompost.

\subsection{More mature and stable}

To assess the stability and maturity of compost and vermicompost, various techniques were used by Soobhany et al. (2017a). They reported that differential scanning calorimetry (DSC) curves showed that there was an intense degradation of complex and larger biomolecules to simpler compounds in vermicompost compared to compost. In addition, thermogravimetric curves also show that vermicompost has lower mass loss as compared to compost which indicates that it is more stable than compost.

\subsection{Less heavy metals}

Singh et al. (2011) claimed that there is a chance of heavy metals in compost whereas, in vermicast, earthworms remove and accumulate them in their bodies. Dia et al. (2004) also reported that earthworms have the ability to remove excess metals and bioaccumulate them. The earthworms not only turn the organic portion of hazardous waste into available nutrients (Pattnaik and Reddy 2010) but also reduce or remove heavy metals from wastes by accumulating them in their bodies during the vermicomposting process (Gupta et al. 2005; Pattnaik and Reddy 2010).

\subsection{Less pathogens}

Earthworms have the ability to make the environment less suitable for pathogens (Contreras-Ramos et al. 2005; Kadam et al. 2008) by releasing antibiotics which destroys them effectively (Sinha et al. 2010). Bloem et al. (2017) claimed that when composts are added to cultivated lands, pathogenic microbes can live in the soil for several days to months. During composting, the pathogen elimination efficiency relies on the aeration and mixing of different layers of the waste as well as on the type of waste (Heinonen-Tanski et al. 2006). Cao et al. (2016) reported that during 100-day study period in the USA, the number of $E$. coli was not reduced, possibly because the composted waste was not turned and thereby aerated. On the other hand, several studies have revealed that vermicomposting greatly decreases or entirely removes the amount of pathogenic bacteria if vermicomposting is conducted for a reasonable period of time. For instance, no pathogenic bacteria like, Salmonella, Enterobacter, or Shigella could be found during the 60-day vermicomposting of sheep manure relative to the beginning of vermicomposting (Gutiérrez-Miceli et al. 2007). In other studies, vermicomposting of at least 2 months was found to be ample time to eliminate pathogenic bacteria (Karimi et al. 2017).

\subsection{Higher disease suppression}

In contrast to compost and compost tea, both vermicompost and vermicompost tea have a higher potential to suppress diseases. Manandhar and Yami (2008) compared the effectiveness of aerated and non-aerated compost and vermicompost teas on foot rot disease of rice and reported that aerated vermicompost tea provided the highest level of disease control. Similarly, Arancon et al. (2007a) also recorded that when liquid extract of vermicompost and compost was sprayed on tomato seedlings against two spotted spider mites, vermicompost tea substantially avoided plant damage caused by both pests, whereas compost tea has shown no effect on the control of both pests.

\subsection{Enhanced growth and yield of plants}

Several researchers have demonstrated that vermicompost contributes to higher plant growth and yield relative to compost. A comparative study of municipal waste-based compost and vermicompost was done by Tognetti et al. (2005) and they observed that when municipal waste-based compost and vermicompost was applied at the same rate of 20 and $40 \mathrm{~g} \mathrm{~kg}^{-1}$ to ryegrass, the vermicompost results higher ryegrass yield, possibly due to higher nutrient concentrations and higher microbial size and activity. Several other authors have also reported higher growth and yield of plants like green bean and Salvia officinalis by vermicompost as compared to compost (Soobhany et al. 2017b; El-Haddad et al. 2020).

\section{Disease and pest control by vermicompost}

\subsection{Disease suppression}

Interest in the application of vermicompost for the suppression of crop diseases has grown significantly within the last two 
decades as shown by scientific data presented in Table 2 . Much interest has come from the developing countries, where the researchers are highly interested in finding low-cost as well as efficient methods for the management of crop diseases. A comparative analysis was conducted by Szczech and Smolinska (2001) against tomato root rot caused by Phytophthora nicotianae var. nicotianae to evaluate the suppressiveness of the cattle and sewage sludge based vermicompost. They reported that the sewage sludge-based vermicompost could not protect tomato seedlings against the pathogen Phytophthora nicotianae, whereas cow manure vermicompost greatly reduced the pathogen-infection. Chaoui et al. (2002) confirmed that diseases caused by Rhizoctonia in radishes and Pythium in cucumbers significantly decreased in greenhouse and indicated that it was due to the presence of biocontrol agent Trichoderma spp. in the vermicompost. Significant levels of suppression on the disease incidence caused by Verticillium in strawberries and Phomopsis and Sphaerotheca fulginae in grapes were also achieved by them under field conditions. They also reported that vermicompost lost its suppressive ability when it was sterilized, thus persuasively suggesting that the mechanism for suppressing disease is biological. Tomato wilt disease caused by Fusarium oxysporum was significantly suppressed when separate dairy solidbased vermicompost was used (Kannangara et al. 2000). Likewise, control of Phytophthora brassicae, Phytophthora nicotianae, and Rhizoctonia solani (Asciutto et al. 2006; Simsek-Ersahin et al. 2009) have been achieved by vermicast treatments. An instant evaluation of vermicompost as a plant growth enhancer and bio-control agent on damping-off of tomatoes caused by Rhizoctonia solani was performed by Rivera et al. (2004). The microbial composition of plant growth media supplemented with vermicompost at $0,25,50$, 75 , and $100 \%$ (by volume) levels was also investigated. When vermicast was applied @ 20\%, the incidence of Rhizoctonia decreased and at $25-100 \%$, vermicompost not only inhibited damping-off, but also encouraged the production of seedlings. They concluded that vermicomposts can be used as an efficient alternative to control damping-off of tomato and may be used as an effective tool in promoting the growth of seedlings as well. A comparative study by Sahni et al. (2008b) on suppressive effect of two nonconventional chemicals oxalic acid and zinc sulfate ( $\mathrm{ZnS04})$ and the bio-agent Pseudomonas syringae along with vermicompost was conducted against Sclerotium rolfsii which is responsible for collar rot disease in chickpea. It was observed that the chickpea mortality was greatly reduced by vermicompost amendments as compared to control. However, the suppressive effect against $S$. rolfsii was more efficient when preinoculation was done with chemicals. They revealed that the enhancement of strength and stimulation of defense mechanism like that of systemic acquired resistance in chick pea plants was due to the combined effect of chemicals and vermicompost. Gill and Walia (2014), on the other hand, also stated that the combined application of vermicompost and chemical fertilizers helps to maintain yield stability by correcting auxiliary and micronutrient deficiencies, enhancing the efficacy of related nutrients and ensuring optimal physical conditions for the soil.

Apart from using compost or biocontrol agents individually, the fortification of compost with bio-control agents has been suggested to increase the colonization process of biological agents in composts (Sahni et al. 2008a; Sarma et al. 2010). Numerous composts and biofortified composts have been reported to decrease the number of pathogens and defend crops against soil borne pathogenic agents when applied as soil amendments (Mokhtar and El-Mougy 2008; Khalil and ElMghrabia 2010). Antagonistic effect of vermicompost and vermicompost fortified with Trichoderma harzianum, Bacillus subtilis and Pseudomonas fluorescens was investigated against Fusarium oxysporum and it was shown that biofortification not only facilitated plant growth but also significantly reduced wilt disease. As these microbial strains have the potential to secrete antifungal metabolites, hydrolytic enzymes, and antibodies (Keswani et al. 2014). In a study done by Basco et al. (2017) on the management of tomato Fusarium wilt by biofortified vermicompost, it was revealed that the vermicompost application alone or after fortification with microbes like Trichoderma harzianum, Pseudomonas fluorescens and Bacillus subtilis significantly enhances growth and nutritional status of tomato plants. It was also found that the incidence of disease was lower in plants treated with vermicompost biofortified with biocontrol agents especially Trichoderma herzianum as compared to the control plants. Similar types of results were found by Rao et al. (2017), in which they reported that when vermicompost was fortified with Bacillus subtilis IIHR BS-2, soft rot disease and root-knot nematode was managed effectively. A recent investigation was done by You et al. (2019) to examine the influence of bamboo waste based vermicompost on damping-off disease of cucumber. It was found that damping-off caused by each strain of Pythium aphanidermatum, P. ultimum var. ultimum, and Rhizoctonia solani AG1-IB was substantially decreased by vermicompost as compared to an autoclaved vermicompost and a commercial nursery medium. This was attributed to the higher diversity and activity of microbes in vermicompost as compared to autoclaved vermicompost and commercial medium. Other authors have also reported that when organic amendments, including vermicompost, were applied, the incidence of diseases like late blight in potato and Fusarium wilt in cucumber was reduced significantly (Peerzada et al. 2020; Zhang et al. 2020). 
Table 2 Disease and pest control by vermicompost

\begin{tabular}{lllll}
\hline S. No & Disease/pest & Crop & Treatment & References \\
\hline 1. & Jassid (Empoasca verri), aphid & Groundnut & Vermicompost & Rao et al. (2001) \\
2. & Dampis craccivora) & Cucumbers and Radishes & Vermicompost & Chaoui et al. (2002) \\
3. & Damping-off & Tomatoes & Vermicompost & Rivera et al. (2004) \\
4. & Damping-off & Patience plant (Impatiens walleriana) $)$ & Vermicompost & Asciutto et al. (2006) \\
5. & Tetranychus urticae, Pseudococcus sp. & Bush beans, Eggplant, tomato, & Vermicompost & Arancon et al. (2007b) \\
& $\quad$ Myzus persicae & Cucumber, and Cabbage & Vermicompost & Sahni et al. (2008a) \\
6. & Collar rot & Chickpea & Vermicompost & Gopalakrishnan et al. (2011) \\
7. & Fusarium wilt & Chick pea & Vermicompost & Little and Cardoza (2011) \\
8. & Helicoverpa zea and Pieris rapae & Cabbage & Vermicompost & Nath et al. (2011) \\
9. & Meloidogyne incognita & Brinjal & Vermicompost & Cardoza and Buhler (2012) \\
10. & Earworm (Helicoverpa zea) & Corn plant & Vermicompost & Nath and Singh (2012) \\
11. & Aphid (Lipaphis rysimi) & Mustard & Vermicompost & Basco et al. (2017) \\
12. & Fusarium wilt & Tomato & Vermicompost & You et al. (2019) \\
13. & Damping- off & Cucumber & Vermicompost & Jangra et al. (2019) \\
14. & Polyphagotarsonemus latus & Chili & Vermicompost & Peerzada et al. (2020) \\
15. & Late blight disease & Potato & Vermicompost & Zhang et al. 2020 \\
16. & Fusarium wilt & Cucumber & &
\end{tabular}

\subsection{Pest control}

Vermicasts can also manage arthropod pests such as caterpillars: like tomato hornworms, cabbage white caterpillars and cucumber beetles including sucking arthropods such as aphids, spider mites and mealy bugs (Arancon et al. 2005). Arancon and Edwards (2004) and Arancon et al. (2005) were the first who reported that vermicompost resulted substantial control of mealy bug attacks on cucumbers and tomatoes, twospotted spider mite attacks (Tetranychus urticae) on bush beans and egg plants and attacks by aphids (Myzus persicae) on cabbages by low application levels of food waste vermicompost (Arancon et al. 2007a). Food waste-based vermicompost effect was also examined by Yardim et al. (2006) on a number of spotted cucumber beetles (Diabotrica undecimpunctata) and adult striped cucumber beetles (Acalymma vittatum) on cucumbers and larval hornworms on tomatoes (Manduca quinquemaculata) in both field and green-house conditions. Under field conditions, the tomato and cucumber plants were cultivated with two distinct vermicompost doses (1.25 and $2.5 \mathrm{t} / \mathrm{ha}$ ) comparatively with chemical fertilizer. It was found that population of cucumber beetles were substantially suppressed on cucumber plants at both application levels. In the glasshouse, tomato and cucumber plants were developed in Metro-mix 360 supplemented by vermicompost food waste of 0,20 , or $40 \%$. Both 20 and $40 \%$ vermicompost replacements significantly reduced damage to cucumber and tomato plants. Vermicompost also has a positive effect on the occurrence and number of plant nematodes. Swathi et al. (1998) first reported that applying vermicast to soil at a rate $1 \mathrm{~kg}$ per meter square considerably reduced the occurrence of the Meloidogyne incognita in tobacco plants. Similar type of reduction was also witnessed by Morra et al. (1998) in plant infection caused by Meloidogyne incognita. In another investigation, vermicompost produced from two different sources has been observed to be efficient in reducing corn earworm (Helicoverpa zea) in its adult and immature phases on corn plant (Zea mays). The percentage of consumed maize leaves as well as the mean amount of Helicoverpa zea eggs has shown to be decreased compared to controls on the application of both the sources of vermicomposts (Cardoza and Buhler 2012).

Sometimes, bio-pesticides are also added along with vermicomposts to improve overall suppressiveness against pests. For instance, in case of brinjal crop, the combination of biopesticides and vermicompost has observed to be effective against nematode (Meloidogyne incognita). The crop yield of brinjal plant was also substantially improved by this joint application (Nath et al. 2011). Recently, an investigation was done by Jangra et al. (2019) to study the effectiveness of vermicompost on management of chili pest Polyphagotarsonemus latus. It was observed that when plants were applied with vermicompost at the rate of $5 \mathrm{t} / \mathrm{ha}$, both the population and number of eggs $(5.05$ eggs/leaf) laid by Polyphagotarsonemus latus decreased significantly as compared to control (6.18 eggs/leaf). They revealed that it was due to the existence of both micro- and macronutrients in vermicompost which makes the defensive system of plants stronger against pest infestation. 


\section{Disease and pest control by vermicompost tea}

\subsection{Disease suppression}

In agriculture, the usage of vermicompost tea is growing because of its potential to manage the diversity of air and soil borne diseases (Table 3). Keeping that in view, the liquid extracts of composts are seen as alternative options to the use of traditional chemical fungicides and pesticides in response to the growing need for agriculture and food protection for environmental sustainability (Pane et al. 2012). The efficacy of compost tea can be different due to variations in compost types, sources, and preparation methods used (Egwunatum and Lane 2009; Pane et al. 2012). However, it has been documented that the most excellent outcomes are achieved by applying aerated tea instead of non- aerated tea (Martin 2014), possibly because dissolved oxygen promotes microbial diversity and activity (Arancon et al. 2007b). Over the last 10 years, the application of vermicompost tea as a bio-control agent has increased significantly. It was stated that the mycelial growth of Botrytis cinerea, Sclerotinia sclerotiorum, Rhizoctonia solani, Corticium rolfsii, and Fusarium oxysporum was inhibited significantly by liquid extracts from vermicomposts (Nakasone et al. 1999). An investigation was conducted by Singh et al. (2003) to test the effect of aqueous extract of vermicast by spraying it directly over the leaves against powdery mildews of pea and balsam caused by Erysiphe pisi and Erysiphe cichoracearum, respectively. The in vitro spore germination of various saprophytic and phytopathogenic fungi (Alternaria brassicae, Alternaria solani, Curvularia penniseti, Curvularia palliscens, Helminthosporium speciferum, Helminthosporium penniseti) was substantially inhibited by aqueous vermicompost. However, under field conditions, the postinoculation application provided higher protection to pea than pre-inoculation, whereas against powdery mildew on balsam, both pre- and post-inoculation treatments were found to be efficient. That variable influence, however, is difficult to explain. But these findings suggest the high potential of using vermicompost as a feasible substitute technique for controlling plant diseases. Singh et al. (2003) recommended that farmers should apply these liquid solutions directly to leaves as a simple, inexpensive and environment friendly crop protection method with high yield potential. Zaller (2006) investigated the influence of vermicast tea on the growth, yield, fruit quality and the disease inhibition potential against Phytophthora infestans on three varieties of tomatoes. He noted a reduced vulnerability of leaves, stems, and fruits of tomato plants against disease caused by Phytophthora infestans as compared to water sprinkled control plants. A comparative analysis was conducted by Manandhar and Yami (2008) to investigate the ability of liquid solutions of aerobic compost and vermicompost on Fusarium moniliforme causing root rot disease in rice. Four treatments were applied as aerated vermicast tea, non-aerated vermicast tea, aerated compost tea and non-aerated compost tea. They stated that highest control effectiveness was shown by aerated vermicompost tea, while non-aerated compost tea obtained the least effects. They summarized that the efficiency of tea appears to be dependent on several factors, including preparation process, extraction period, form of compost used (compost/vermicompost), and crops tested. In a recent experiment conducted by Barman et al. (2013) against fusarium wilt of brinjal plant, it was found that even at low concentration $(0.1 \%)$ of vermicompost tea, the pathogen growth and development was inhibited significantly.

Table 3 Disease and pest control by vermicompost tea

\begin{tabular}{|c|c|c|c|c|}
\hline S. No & Disease/pest & Crop & Treatment & References \\
\hline 1. & Powdery mildew & Pea and Balsam & Vermicompost tea & Singh et al. (2003) \\
\hline 2. & Late blight & Tomatoes & Vermicompost tea & Zaller (2006) \\
\hline 3. & Foot rot & Rice & Vermicompost tea & Manandhar and Yami (2008) \\
\hline 4. & Acalymma vittatum, Manduca sexta & Cucumber and Tomato & Vermicompost tea & Edwards et al. (2010) \\
\hline 5. & Fusarium wilt & Brinjal & Vermicompost tea & Barman et al. (2013) \\
\hline 6. & Reniform nematode & Zucchini & Vermicompost tea & Wang et al. (2014) \\
\hline 7. & Sclerotium cepivorum & Onion & Vermicompost tea & Amin et al. (2016) \\
\hline 8. & Meloidogyne incognita & Zucchini and Cucumber & Vermicompost tea & Mishra et al. (2017) \\
\hline 9. & $\begin{array}{l}\text { Meloidogyne incognita and } \\
\text { Rotylenchulus reniformis }\end{array}$ & Cucumber & Vermicompost tea & You et al. (2018) \\
\hline 9. & Meloidogyne incognita & Banana plant & $\begin{array}{l}\text { Vermicompost and } \\
\text { Vermicompost tea }\end{array}$ & Awad-Allah and Khalil (2019) \\
\hline 10. & Meloidogyne incognita & Tomato & Vermicompost tea & Liu et al. (2019) \\
\hline 11. & Meloidogyne incognita & Tomato and bell pepper & Vermicompost tea & dos Santos et al. (2020) \\
\hline
\end{tabular}


Moreover, at the high concentration of vermicompost tea (5\%), not only brinjal growth and development was highest, but induction of disease resistance was highest in treatment plants compared to control plants. This study had also confirmed that the application of vermicompost encourages microbial diversity which not just enhances plant growth but also induces disease tolerance in plants.

\subsection{Pest control}

In India, there is an annual loss of around $20-30 \%$ of crop productivity due to pest damage, which costs between US\$ 14.94-24.89 billion. Vermicompost teas have significant potential to kill or suppress pests. A study by Arancon et al. (2007a) reported that drenching of vermicast tea suppresses spider mite damage. By applying vermicompost tea, the soluble phenolic compounds reach the plant and make the plant tissues unpalatable, thereby disturbing survival and reproduction rate of pests (Pathma and Sakthivel 2012). It is reported by Edwards et al. (2007) that earthworms take-up soil substances, swallow humic acids through their guts and finally excrete polychlorinated and monomeric phenols into the final vermicast. Vast microbial communities and their activities in vermicompost tea led to the release of nutrients in slow but balanced manner that reduces nitrogen inputs, improves phenol content of plants, thus resulting in plant tolerance against pests (Pathma and Sakthivel 2012). On plant arthropod pests, a set of experiments was conducted by Arancon et al. (2007b) on twospotted spider mite: Tetranychus urticae and Myzus persicae. After spraying either compost or vermicompost teas on to the tomato seedlings, the pests were released in to the cages where the seedlings were grown. The control efficiency of vermicast tea was higher than that of traditional compost tea in both plant pest experiments. Edwards et al. (2010) studied the influence of vermicast tea on different pests and reported that all vermicast solutions decreased the population of pests; however, maximum inhibition was observed in $20 \%$ vermicompost solution and minimum in 5\% solution. They indicated that the average damage rate per plant decreased with an increase in the concentration of extract and concluded that $20 \%$ extract is the most efficient to manage pests. They further reported that the uptake of phenolic substances by plant tissues from vermicompost tea makes the plants unacceptable for pests, thus reducing their survival and reproduction.

Vermicompost tea has also a tremendous potential against plant parasitic nematodes. Nematode Meloidogyne spp. which is responsible for root-knot is highly destructive and common disease in many agricultural crops like tomato (Hunt and Handoo 2009). Nematode not just directly reduces crop productivity but also making the plants more vulnerable to fungal and bacterial diseases (Ashraf and Khan 2010). This nematode has a great potential to reduce yields from a wide range of crops around the globe, and against which no effective control mechanism has yet been developed. Efficacy of vermicompost tea against nematodes and arthropod pests has been verified by number of researchers (Edwards et al. 2007; Wang et al. 2014; Mishra et al. 2017). They conducted various glasshouse and field tests to check the effectiveness of vermicast tea as a soil drench in tomato seedlings infected with Meloidogyne hapla eggs and reported a significant reduction in the amount of root knot galls on tomato roots and a substantial influence on seedling growth. Such response of plants may be due to the development of growth enhancers like gibberellins, auxins coupled with humic acids that also function as plant growth regulators (Oka 2010; Arancon et al. 2012). A comparative investigation was done to study the influence of vermicompost, vermicompost tea, bio-agent and nematicide fenamiphos against Meloidogyne incognita infecting banana under lab and field conditions. In lab conditions, it was found that, with the increase in concentration and exposure time, the toxicity of vermicompost tea and bio-agent increased against the nematode, and under field conditions, the number of galls, egg masses, and population of nematode suppressed significantly by all the treatments of nematicide, bioagent, vermicompost, and vermicompost tea as compared to non-treated plants (Awad-Allah and Khalil 2019). Population density of Meloidogyne incognita in soil was also significantly suppressed and reduction increased from 75.73$85.61 \%, 72.06-82.28 \%, 71.97-79.16 \%, 71.30-77.33 \%$ after the first and second application of fenamiphos, vermicompost, bioagent, and vermicompost tea, respectively. Therefore, they concluded that bioagent vermicompost, and vermicompost tea had nematicidal potential against Meloidogyne incognita. Similar types of experiments were conducted by You et al. (2018) under field, greenhouse, and laboratory conditions to compare suppressive effect of weed- and vegetable-based vermicompost tea against nematode $M$. incognita and Rotylenchulus reniformis. Both vermicompost teas suppressed Meloidogyne incognita egg hatching compared to water control, while only weed-based vermicompost tea suppressed Rotylenchulus reniformis egg hatching. They revealed that the suppressive ability of weed-based vermicompost tea was more constant than vegetable-based vermicompost tea, probably because of higher microbial growth promoted by higher carbon content. These findings were consistent with Mishra et al. (2017) who found that vermicompost tea suppressed hatching and root penetration of $M$. incognita but unfortunately the reproduction and root gall formation was not suppressed by vermicompost tea over time.

\section{Mechanism of disease suppression by vermicompost and vermicompost tea}

In general, the research on plant disease control by vermicompost and vermicompost tea has revealed that the 
suppression effect is biological in nature rather than chemical (Szczech 1999; Simsek-Ersahin et al. 2009). The majority of scientific literature has revealed that after sterilization or pasteurization, composts lost its suppressive effect against diseases (Cotxarrera et al. 2002; Van Beneden et al. 2010; Joshi et al. 2015). Different mechanisms which have been identified to be responsible for the suppression of diseases are classified into two broad categories, i.e., general suppression mechanism and specific suppression mechanism, which are analyzed in the following sections.

\subsection{General suppression mechanism}

This mechanism would be more prominent in the case of vermicomposts, as vermicomposting significantly increases both the diversity and the number of beneficial microbes (Edwards et al. 2004). General suppression is characterized by nutrient competition, antibiosis, hyperparasitism or predation, and systemic-induced resistance (Hoitink and Grebus 1997; Pieterse et al. 2014; Baum et al. 2015). These four mechanisms are shown in Fig. 3 and discussed briefly in the following sub-sections.

\subsubsection{Competition}

In the use of compost produced either by composting or vermicomposting, competition is the key factor in the context of general disease suppression mechanism. Hence, the intensity of disease suppressiveness is characteristically linked to the amount of total microbial biomass or activity in a soil. The larger the number of active microbes in the soil, the greater the capability of soil to utilize nutrients, energy, carbon and space thereby, reducing the availability of nutrients to pathogens. It occurs when a beneficial microorganism out-competes a phytopathogen for a resource which may result in disease suppression. For instance, some microbes under iron limiting conditions produce low molecular weight ferric-specific ligands (siderophores) which reduce disease occurrence by reducing the availability of iron to pathogens such as Pythium species (Srivastava et al. 2010). It was stated by Pantelides et al. (2009) that the key mechanism of action of the nonpathogenic Fusarium oxysporum was competition for space or nutrients on the root surface of host plants against Verticillium dahlia. Basically, any treatment that enhances overall activity of microbes in the soil can improve general suppression of pathogen by enhancing nutrient competition. The mycorrhizal fungi that can be transmitted and multiplied in the soil by worms (Turk et al. 2006) may defend plant roots from diseases through various means, such as antibiotic secretion, increased nutrient absorption by plant roots or by forming physical barriers. Among the beneficial fungi, Trichoderma species is probably the mostly used organism for agricultural yield enhancement (Jogaiah et al. 2013; Abdelrahman et al. 2016) and some species like Trichoderma virens have been accepted as a destructive mycoparasite that have the ability to compete with pathogens at the infection site (Djonovic et al. 2007).

\subsubsection{Antibiosis}

Antibiosis refers to an interaction between individuals where one organism directly affects other organisms by producing non-toxic and/or unique metabolites or antibiotics (Litterick and Wood 2009). For instance, Chernin et al. (1995) stated that chitinolytic enzymes produced by Enterobacter strains were observed to be antagonistic to various pathogens including Rhizoctonia solani. The toxin "gliotoxin," which is isolated from Gliocladium virens, was found to be antagonistic
Fig. 3 Different mechanisms of disease suppression by vermicompost and vermicompost tea Vermicompost products enhance the microbial number and diversity around the root zone of the plants, and these microbes via different mechanisms protect the plants, either by stimulating resistance in plants against phytopathogens, by increasing competition for nutrients, releasing antibiotic substances against pathogens or by directly parasitizing the phytopathogens
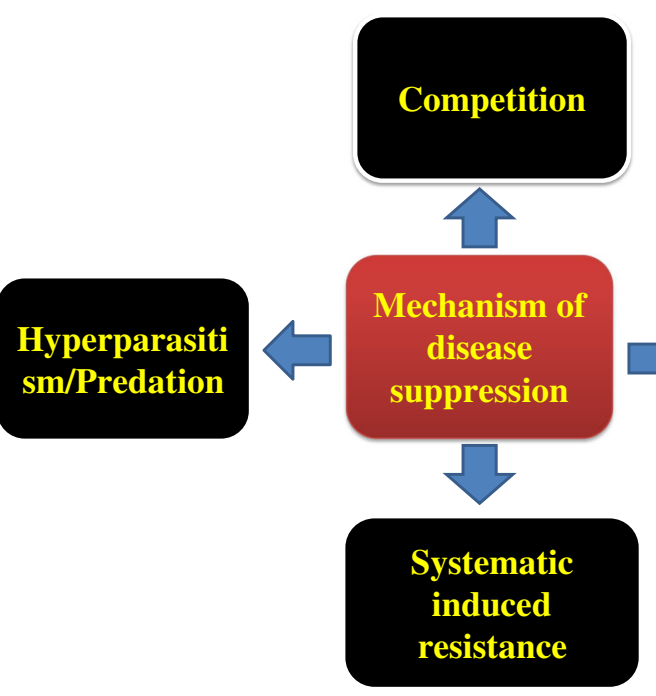
against Pythium ultimum (Roberts and Lumsden 1990; Lumsden et al. 1992). Suarez-Estrella et al. (2007) also stated that bacteria and fungi isolated from fruit-based compost show antagonistic activity against many phytopathogens including Fusarium oxysporum. Similarly, Bacillus subtilis also secretes an antibiotic, zwittermicin A, which has been identified as poisonous to the Pythium torulosum, a plant pathogen. Bacillus subtilis, Enterobacter, Pseudomonas, Gliocladium virens and Trichoderma harzianum present in compost and compost tea are known to secrete enzymes or antibiotics that can prevent growth, development and replication of several plant pathogens (Brinton and Droffner 1995). For instance, Vinale et al. (2009) point out that strain Trichoderma harzianum produced a specific metabolite known as harzianic acid that showed antibiotic activity against pathogenic agents such as Pythium irregulare, Rhizoctonia solani, and Sclerotia sclerotiorum. In addition, Trichoderma strains have significant antagonistic and mycoparasitic effects on phytopathogens and consequently can decrease the severity of plant diseases (Viterbo and Horwitz 2010; Elsharkawy et al. 2013).

\subsubsection{Hyperparasitism/predation}

Hyperparasitism refers to the phenomenon in which phylogenetically unrelated microorganisms colonize pathogens, which leads to their death (Hoitink et al. 1997). In comparison, when pathogens are usually killed via phagocytosis, it is known as microbial predation (Matz et al. 2007). As per Hoitink et al. (1996), parasitism is greatly influenced by the degree of decomposition of organic matter and the presence of carbon and other easily available nutrients, as they limit the production and effect of lytic enzymes that are used to destroy pathogens (Hoitink et al. 1996). For example, in fresh barkbased compost, many microbes like Trichoderma hamatum and Trichoderma harzianum produce several lytic enzymes but they do not attack plant pathogen Rhizoctonia solani directly. However, as the composting process continues, the chitinase genes of Trichoderma species get activated because of easily accessible glucose and cellulose which then parasitizes Rhizoctonia solani by secreting enzyme chitinase (Kwok et al. 1987; Benitez et al. 2004). One more example of parasitism is the biocontrol fungus Trichoderma harzianum that coils around the Pythium ultimum hyphae, punctures its cell wall, and consumes the plant pathogen (Benhamou and Chet 1997).

\subsubsection{Induced systemic resistance}

As an environmentally friendly and cost-effective platform for stimulating disease resistance via induced systemic resistance (ISR) and promoting plant growth for sustainable crop production, beneficial microbes have gained considerable attention (Abdelrahman et al. 2016; Harel et al. 2014). For instance, when compost was added to a portion of cucumber root using a split root system, systemic resistance was induced against pathogen Pythium root rot (Lievens et al. 2001). Many authors have also stated that resistance in crops against phytophthora species and Botrytis cinerea has been boosted by Trichoderma species isolated from compost (Horst et al. 2005; Hoitink et al. 2006). Based on the identification of inductive resistance-related compounds, it was concluded that in host okra plants, resistance was stimulated when non-sterilized compost tea was applied (Siddiqui et al. 2008). Similarly, Sang and Kim (2011) mentioned that protection against disease anthracnose in pepper and cucumber was due to ISR, mediated by compost extract.

\subsection{Specific suppression mechanism}

In this mechanism, a specific organism suppresses a recognized pathogen or one in which repression is only enabled by a small range of microbes. Here, for the specific intention of suppressing disease occurrence, a bio-control agent isolated from compost/vermicompost is added to the soil (Hoitink et al. 1997). It is assumed that this mechanism is responsible for the destruction of phytopathogens like Rhizoctonia solani and Sclerotium rolfsii. Some selected strains of nonpathogenic bacteria like genus Bacillus have the ability to colonize plant roots and induce specific resistance in both the roots, shoots, and leaves of the plant. Under greenhouse conditions, Bacillus subtilis strain was used by Punja et al. (2016) to manage post-harvest infection in fruits. Such strains were also found to have inhibitory effect against Botrytis cinerea, the main cause responsible for fruit rot of tomato (Kilani-Feki et al. 2016). Similarly, 10 rhizobacterial strains were used to control tomato wilt and it was observed that only two strains Bacillus amyloliquefaciens and Ochrobactrum intermedium considerably reduced the wilt incidence and also greatly improved seedlings vigor index (i.e., percentage of seed germination and mean height of seedlings) (Gowtham et al. 2016).

\section{Mechanism of pest control by vermicompost and vermicompost tea}

The mechanisms by which vermicompost and vermicompost tea suppresses or controls pest attacks are numerous but speculative at the same time (Edwards et al. 2004). Based on the abovementioned research findings, the four possible mechanisms can be identified to be responsible for the suppression of pest attacks. These are release of phenolic substances, increase in number and diversity of active microbes and pathogenic nematodes, release of toxic substances and increase in availability of nutrients to plants. Further studies are required 
to support these hypotheses and to recognize the suitable mechanisms by which these organic amendments regulate pests. These mechanisms are shown in Fig. 4 and discussed below briefly.

\subsection{Release of phenolic substances}

A number of studies have confirmed that insect and nematode attacks are suppressed significantly after applying either vermicompost or vermicompost tea. Edwards et al. (2010) reported that both the survival and reproductive potential of Acalymma vittatum (cucumber beetle) and Manduca sexta (Tobacco hornworm) were substantially reduced by applying vermicompost tea and concluded to be due to the release of phenolic substances which makes the plant tissues unpalatable to the pests.

\subsection{Increase in number of predatory nematodes and beneficial microbes}

Both vermicompost and vermicompost tea are rich sources of beneficial microbes and their addition to plants often increases the number of microbes. These beneficial microbes not only increase plant growth but also induce plant resistance against various pathogens (Barman et al. 2013). By applying these organic amendments like vermicompost tea, the number and diversity of predatory nematodes also increase in soil overtime which strengths the soil food web (You et al. 2018). These predators in-turn negatively affect the number of pests by attacking them directly (Edwards 2004; Renčo et al. 2011). Renčo and Kovácik (2015) reported that both the number of eggs and juveniles of potato cyst nematodes Globodera rostochiensis and Globodera pallida were substantially decreased when vermicompost tea was applied. Predator prey interaction was also believed to be responsible for reduction in the number of plant nematodes (Edwards et al. 2004). Similar type of mechanism was also found to be responsible for decreasing the number of Meloidogyne incognita and Rotylenchulus reniformis eggs and juveniles when treated with vermicompost tea and reported to be due to higher number of beneficial microbes present in vermicompost tea (You et al. 2018).

\subsection{Release of some toxic chemicals}

A number of investigations have revealed that plant nematodes and arthropods can be suppressed by the presence of toxic chemicals like antibiotics (Munroe 2007), ammonia, zinc, and hydrogen sulfide in the vermicompost (Edwards et al. 2004). These toxic substances are released in the soil when organic substances are degraded and have the ability to destroy plant pests by directly killing them (RodríguezKábana 1986).

\subsection{Overall increase in nutrient availability}

The introduction of vermicompost not only provides beneficial microbes, growth hormones like gibberellins, auxins etc., but also provides both macro and micronutrients like N, P, K, calcium, boron and magnesium to the plants (Yatoo et al. 2020), which increases their potential to defend themselves from pest attacks (Ramesh 2000; Arancon et al. 2005). Patriquin et al. (1995) also reported that when vermicompost was added, organic nitrogen was released gradually as compared to chemical fertilizers thereby making plants less vulnerable to pest attacks. Similarly, Jangra et al. (2019) also
Fig. 4 Different mechanisms of pest control by vermicompost and vermicompost tea. The addition of vermicompost products increases microbial diversity, the availability of nutrients and release some toxic substances which protects the plants, either by killing pathogens directly, making plant tissues unpalatable for pests or by enhancing plant's defensive system against pest invasion

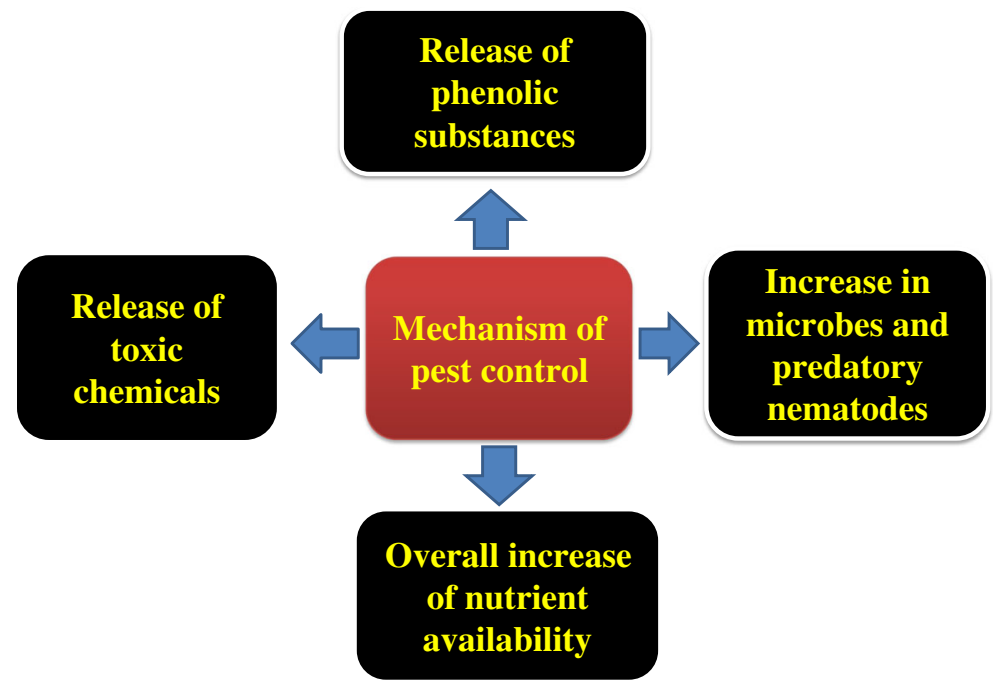


stated that when vermicast was added @ 5 tons per hectare, the population and number of Polyphagotarsonemus latus eggs decreased substantially as compared to control plants. They concluded that it was due to the existence of nutrients in vermicompost which makes plant's defensive system stronger against pest invasion.

\section{Factors affecting disease and pest control potential of vermicompost and vermicompost tea}

There are number of factors that affect the quality of vermicompost and vermicompost tea, which in-turn affect their ability of disease and pest suppressiveness. The important factors are compost grade, compost maturity, brewing, aeration, temperature, $\mathrm{pH}$, microbial inoculants, nutrient supplements, and compost to water ratio (Fig. 5). Some of the important factors are discussed below briefly.

\subsection{Compost source, quality, and maturity}

Vermicompost quality varies and depends on various factors like species of earthworm, raw material used, and age of compost. Many authors have stated that compost maturity (Serra-Wittling et al. 1996), feedstock source (Termorshuizen et al. 2006), degree of organic waste decomposition, physico-chemical and biological properties of compost, brewing time, addition of microbial and nutrient supplements all affect the compost and compost tea's disease suppressive ability (Litterick and Wood 2009; Siddiqui et al. 2009; Martin and Brathwaite 2012; Islam et al. 2016b; Mengesha et al. 2017). Pane et al. (2011) observed that animal manure-based compost exhibited the highest and most constant inhibition of Pythium ultimum, Sclerotinia minor and Rhizoctonia solani. Erhart et al. (1999), on the other hand, showed that compost made from grape marc had neutral or encouraging effects on Pythium rot disease. Others have also reported that lignocellulosic substance based compost constantly reduce root rot disease (Hoitink 1980; Kuter et al. 1983). You et al. (2018) reported that when weed and vegetable based vermicompost teas were applied against $M$. incognita and $R$. reniformis, though both of them suppressed $M$. incognita egg hatching, but only weed based vermicompost tea suppressed $R$. reniformis egg hatching. An evaluation of the degree of compost maturity and organic waste decomposition has also been considered critical in assessing disease control potential of compost. De Ceuster and Hoitink (1999) have reported that fresh organic matter generally does not support biological disease suppression, even if supplemented with biological agents of confirmed efficiency. It is widely agreed that premature compost often possesses toxic substances that affects crop growth and make them attacked by phytopathogens and pests, and that adding older and more humidified peats decreases or eradicates suppressiveness due to their inability to sustain bio-control

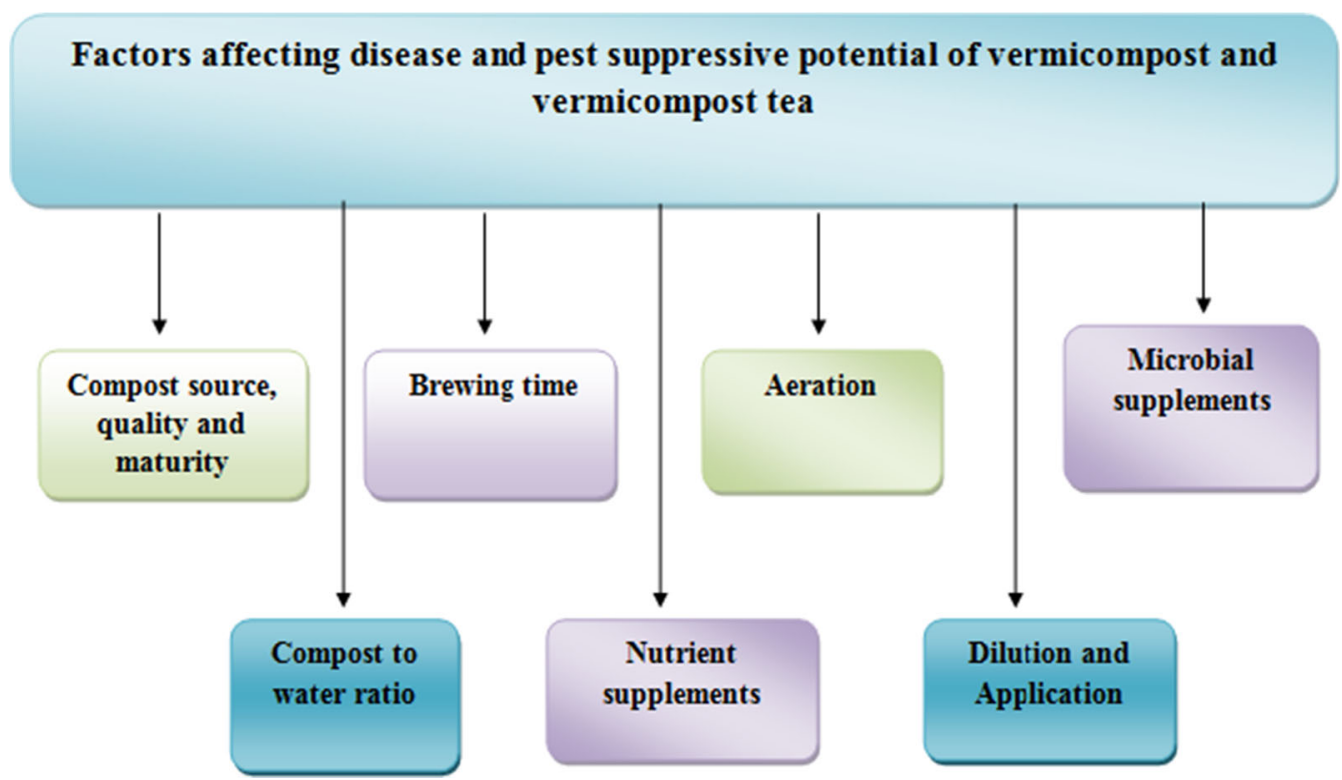

Fig. 5 Some important factors affecting diseases and pest suppressive potential of vermicompost and vermicompost tea. The quality of vermicompost products depends on the nature of raw material, methodology, microbial, and nutritional supplements etc. The higher the quality of vermicompost, higher the quality of its liquid solution, and higher the disease and pest management 
activity of microorganisms (Hoitink et al.1993; Hoitink and Boehm 1999).

\subsection{Compost to water ratio}

It is recommended that chlorine-free drinking water be utilized to prepare compost tea or any dilution thereof irrespective of the method of preparation. During the brewing process, these chemicals can inhibit the growth and proliferation of microorganisms. The optimum compost to water ratio varies and depends on some factors, including the fermentation technique, compost type and application purpose. More water and little compost can result into more dilution of compost tea with low amount of beneficial microbes and nutrients, whereas less water and more compost may not allow maximum nutrients and microbes to get extracted from compost (Ingham 2005). Numerous researchers have used the methodology developed by Weltzien (1990) who used the compost to water ratio of 1:3-1:10. Phytophthora infestans was significantly suppressed when compost tea was applied, however, no difference was observed in disease suppression between the ratios of $1: 3$ and $1: 10$. But there was a difference in disease suppression with $1: 50$ ratio as compared to $1: 3$ and $1: 10$ ratio (Weltzien 1990). Significant reduction in onion white rot was also observed when vermicompost tea at a ratio of 1:10 was utilized (Amin et al. 2016). On evaluating the effect of various types of compost teas against powdery mildew, Seddigh and Kiani (2018) observed that powdery mildew was efficiently controlled at a ratio of 1:8 as compared to $1: 16$ ratio under glass house conditions. Pant (2011) also observed that the utilization of vermicompost tea at a ratio of 1:10-1:100 enhanced growth and yield of plant, thus suggesting that the ideal ratio ranges between 1:10-1:20. Various other investigations have also confirmed that reducing the ratio to $1: 10$ is observed to be efficient in disease inhibition and yield enhancement (Weltzien 1991; Scheuerell and Mahaffee 2002).

\subsection{Brewing time}

Brewing time is a significant factor which contributes to the quality and effectiveness of compost tea. During the brewing time, nutrients and plant growth promoters get extracted from solid compost into the liquid extract which are then easily assimilated by the plants when applied (El-Din and Hendawy 2010; Pant 2011). Compost tea needs to be fermented to the level that most of the nutrients and beneficial microorganisms could be taken out into the solution (Ingham 2005). Maximum extraction of microbes and nutrients from the compost may be prevented when brewing occurs for shorter period of time, while brewing for longer period may favor the microbial immobilization of extracted nutrients leading to the inactivation of microorganisms once all available food is consumed (Ingham 2005). However, for brewing, the general trend is $24 \mathrm{~h}$ for aerated tea, while 5-7 days for nonaerated tea. Other researchers recommended that while 24-h brewing period is good for fertilization, 7-14-day brewing period is better when making liquid solution with optimum disease inhibition properties (Weltzien 1990; Cantisano 1998). In general, non-aerated compost tea (NCT) needs more brewing time as compared to aerated compost tea (ACT) (Diver 2001; Ingham 2005). Weltzien (1991) hypothesized that in order to provide required time for facultative anaerobic microbes to dominate and their metabolites to accumulate, 1to 2-week brewing period is typically required for non-aerated compost tea. Ketterer et al. (1992) investigated suppression of Botrytis with 1-, 3-, 7-, and 14-day brewed non-aerated tea and found the highest inhibition with one-week brewed compost tea. Litterick and Wood (2009) reported that in general the optimal time required is believed to be relied on the source of compost and method of brewing, although not verified by any data. However, the trend is still $24 \mathrm{~h}$ for aerated and 1 week for non-aerated compost tea.

\subsection{Nutrient supplements}

Nutrient supplements are mainly applied to enhance total microbial biomass or the number of a particular group of microbes that are assumed to have positive effects. During the brewing process, supplements like kelp, humic acids, and molasses are added to support the enrichment of microbes (Scheuerell 2002; Naidu et al. 2010). As per Scheuerell and Mahaffee (2004), fermentation nutrients are capable of inhibiting or enhancing growth rates of various kinds of microbes. Aerated tea supplemented with rock dust, humic acid, and kelp showed considerable reduction of damping-off disease in cucumber plants cultivated in pot media (Scheuerell and Mahaffee 2004). While several other researchers have observed that nutrient amendments increased (Tian and Zheng 2013), decreased (Scheuerell and Mahaffee 2004), or had no considerable influence on compost tea's disease inhibition properties (Elad and Shtienberg 1994). For instance, Elad and Shtienberg (1994) stated that nutrient supplementation to the non-aerated compost tea did not usually enhance the suppression of gray mold in pepper, tomato, and grape plants. Scheuerell and Mahaffee (2006) observed that while nutrient additions usually enhanced microbial populations in aerated tea, higher gray mold disease reduction was not constantly achieved. However, around $67 \%$ batches of aerated tea supplemented with rock dust, kelp extract and humic acid considerably suppressed the disease. But the supplementation of nutrients must be done with extreme care, as recent investigations have shown that compost tea amended with molasses or other sugars appears to promote the growth of human pathogens like E. coli and Salmonella (Ingram and Millner 2007; Palmer et al. 2010). Molasses especially can lead to the proliferation of harmful bacteria, which means that when fresh 
food is intended for human use, nutrient supplementation should be avoided because of possible risks on human health (Duffy et al. 2004). Further studies are required to check the influence of nutrient amendments on both targeted and nontargeted pathogens (Scheuerell and Mahaffee 2002).

\subsection{Aeration}

Oxygenation during the brewing process of aerated tea has been claimed to promote the growth and propagation of various groups of beneficial microorganisms (Ingham 2005), whereas reduced or absence of aeration during the brewing of nonaerated compost tea may facilitate growth of plant and human pathogens (Scheuerell and Mahaffee 2004; Ingham 2005). Ingham (2005) argues that non-aerated tea is less efficient in reducing plant diseases than aerated tea, as the former contains lower biomass and diversity of beneficial microorganisms. Siddiqui et al. (2009) also revealed that aerated tea suppressed the conidial germination of Choanephora cucurbitarum responsible for wet rot of okra. In addition, they claimed stimulation of host resistance in okra plants. In fact, it is even more argued that teas prepared from vermicompost, because of greater microbial diversity, are more able to manage pests and diseases than other types of teas (Yami and Shrestha 2005; Fracchia et al. 2006; Manandhar and Yami 2008; Vivas et al. 2009). Manandhar and Yami (2008) revealed that while all compost solutions substantially decreased the number of Fusarium moniliforme infected seeds, aerated compost and vermicompost teas contributed to maximum levels of disease suppression as compared to non-aerated vermicompost and compost tea. Aerated compost tea also has one more advantage from farmer's viewpoint that it can be prepared in $24-48 \mathrm{~h}$, whereas non-aerated tea takes 1-2 weeks and also have odor problems (Ingham 2005).

\subsection{Dilution and application}

Dilution and application rate has been stated to influence the effectiveness of compost tea in suppressing plant diseases (Litterick and Wood 2009). Some studies have also found that after dilution, disease suppressiveness of compost tea has either been sustained or reduced (Elad and Shtienberg 1994; Scheuerell and Mahaffee 2004; Hegazy et al. 2015). Likewise, the liquid extracts of un-decomposed materials were suppressive to Phytophthora capsici, but with increasing dilution, disease suppression reduced (Cayuela et al. 2008). Experts have suggested applying compost tea at a rate of 40 $50 \mathrm{~L} / \mathrm{ha}$ for managing plant diseases and in order to get desired results, enough volume should be sprayed so as to reach the entire root zone (Scheuerell 2003; Ingham 2005; Growing Solutions Incorporated 2012). Adequate drenching of vermicompost tea around root zone not just suppresses diseases but also pests (Edwards et al. 2007) because of induced systemic resistance in plants (Mishra et al. 2018). It has been reported that compost tea has pesticide and fertilizer like effects (Islam et al. 2016a), so in most of the cases, it is applied like that of chemical pesticides and biocontrol agents (Mahaffee and Scheuerell 2006). In this context, substantial regulation of disease was found when compost tea was sprayed at less than 14-day interval and 5 to 10 applications every year (Weltzien 1991). Istifadah et al. (2020) observed that when compost extract was applied every 3 or 7 days, diseases like powdery mildew and late blight were reduced by 41 to $49 \%$. Mishra et al. (2016) also reported that population densities of root-knot nematode would not suppress if the plants were drenched every 2 weeks or once a month. Due to the narrow window of expression of these plant defense genes, Meloidogyne incognita can still infect vermicompost tea drenched plants and complete its life cycle over time. Thus, frequent drenching of vermicompost tea at least at 1-week intervals could provide more consistent suppression of M. incognita using tea drenching solution (Mishra et al. 2018). The utilization of vermicompost tea consistently can increase omnivorous nematodes, which indicates gradual enhancement of soil food web over time (You et al. 2018). Among other factors which are required to be assessed to decide whether compost tea can be utilized cost-effectively to manage plant pathogens is the time of application. To this end, Grobe (2003) recommended that evening is the most appropriate time to apply compost tea, when the rate of evaporation is quite low and ultraviolet light, which can be harmful to beneficial microbes, is also low.

\subsection{Microbial supplements}

Microbial supplements are added to increase the effectiveness and certainty of compost and compost tea in order to suppress the disease. They are up to three times as suppressive as unsupplemented composts (Nelson et al. 1983; Cotxarrera et al. 2002). Several studies have reported that composts or microbial supplemented composts have resulted in better disease inhibition and prevented plants from diseases (Khalil and ElMghrabia 2010; Istifadah et al. 2020). The utilization of fortified vermicompost or vermicompost tea has resulted considerable outcomes in terms of productivity and diseases. Priyanka et al. (2014) revealed that highest growth of plant was observed when a combination of vermicompost and microbes Bacillus, Trichoderma and Glomus species were applied. Similar results were also observed by Basco et al. (2017) when vermicompost supplemented with microbes like Trichoderma harzianum, Pseudomonas fluorescens and Bacillus subtilis was applied to tomato plants, not just growth and nutrient level of tomato increased but also Fusarium wilt was considerably reduced. Istifadah et al. (2020) reported that when compost supplemented with antagonistic microbes like Trichoderma harzianum, Papulaspora 
sp., and Paecilomyces fumosoroseus was applied to tomato plants, late blight and powdery mildew disease was suppressed significantly. Adam et al. (2014) also claimed that when Bacillus subtilis was applied to tomato plant, egg masses of $M$. incognita were suppressed by $51 \%$. The use of these organic amendments alone or after biofortification with microbes of agricultural significance will be an environmentfriendly way for disease management that could lead to sustainable agriculture, especially in organic farming (Mishra et al. 2015; Basco et al. 2017; Istifadah et al. 2020).

\section{Conclusion}

The sustainable utilization of these safe and efficient alternatives can provide food security for an ever-rising human population. Although vermicompost and vermicompost tea have shown positive effects on the growth and productivity of various crops, however, there are certain issues for which they are not widely used as inorganic chemicals like they are new and emerging, less available in the market, there is lack of awareness among farmers of their beneficial effects. Moreover, vermicompost tea cannot be stored for long and is required to be utilized within 1 to 2 days as microbes get immobilized. Therefore, to increase the rate of their utilization, more and more farmers should be trained and made aware of them. The overall cost-benefit analysis of vermicast and inorganic chemicals must be evaluated to understand whether these organic modifications are productive for farmers or not and how in future these amendments can be made more efficient so that farmers of both poor and rich countries can take advantage of them without any uncertainty. Work carried out on vermicompost applications for plant protection purposes, in either solid or liquid forms, has shown that they are efficient in suppressing pathogens and pest attacks. Continued research is needed to increase the understanding of mechanisms and factors affecting the suppression of diseases and pests that constantly boost the suppressive potential and the possibilities of integrating them into eco-friendly and sustainable crop production systems. It is also very important to maximize the production and utilization of vermicast products without sacrificing food safety in order to improve crop quality. In the future, plant disease management, currently provided mainly by inorganic chemicals, should be augmented or substituted by these innovative eco-friendly disease control methods. If vermi-products (vermicompost and vermicompost tea) would replace the agrochemicals in crops and fruit production, they would definitely help to create truly sustainable food production systems that will provide chemical-free food for humans in the future.

Acknowledgments Special thanks are due to the Centre of Research for Development, University of Kashmir, Srinagar, Jammu and Kashmir,
India, where the literature survey was done and manuscript wrote. We also thank Shafat Ali for his valuable suggestions.

Data availability Not applicable

\section{Compliance with ethical standards}

Conflict of interest The authors declare that they have no conflict of interest.

Ethics approval Not applicable

Consent to participate Not applicable

Consent for publication Not applicable

Code availability Not applicable

Authors' contributions Conceptualization, writing, original draft, editing, revision, A.M.Y.; supervision, writing-review and editing, M.N.A.; supervision, literature review, editing, Z.A.B.; Literature review, revision, B.H,

\section{References}

Abada KA, Ahmed MA (2014) Management Fusarium wilt of sweet pepper by Bacillus strains. Amer J Life Sci 25:19-25. https://doi. org/10.11648/j.ajls.s.2014020602.13

Abada KA, Hassan EO (2017) Effect of the combination among compost, bioagents and soil solarization on management of strawberry Verticillium wilt. Int J Sci Eng Res 8:88-99. https://doi.org/10. 11648/j.ajls.s.2014020602.16

Abdelrahman M, Abdel-Motaal F, El-Sayed M, Jogaiah S, Shigyo M, Ito S-I, Tran LS (2016) Dissection of Trichoderma longibrachiatuminduced defense in onion (Allium cepa L.) against Fusarium oxysporum f. sp. cepa by target metabolite profiling. Plant Sci 246:128-138. https://doi.org/10.1016/j.plantsci.2016.02.008

Abida N, Muhammad A, Ghulam M (2000) Intrinsic toxicity of some insecticides to egg parasitoid Trichogramma chilonis (Hym. Trichogrammatidae). Bull Institute Trop Agric Kyushu Univ 23: $41-44$

Acevedo IC, Pire R (2004) Effects of vermicompost as substrate amendment on the growth of papaya (Carica papaya L.). Interciencia. 29: 274-279

Adam M, Heuer H, Hallmann J (2014) Bacterial antagonists of fungal pathogens also control root-knot nematodes by induced systemic resistance of tomato plants. PLoS One 9:e90402. https://doi.org/ 10.1371/journal.pone.0090402

Adhikary S (2012) Vermicompost, the story of organic gold: a review. Agric Sci 3:905-917. https://doi.org/10.4236/as.2012.37110

Adiloğlu S, Eryılmaz Açıkgöz F, Solmaz Y, Çaktü E, Adiloğlu A (2018) Effect of vermicompost on the growth and yield of lettuce plant (Lactuca sativa L. var. crispa). Inter J Plant Soil Sci 21:1-5. https://doi.org/10.9734/ijpss/2018/37574

Agrios GN (2005) Plant pathology, 5th edn. Academic Press, San Diego, p 803. https://doi.org/10.1017/s0014479700015507

Allen P (1994) Accumulation profiles of lead and the influence of cadmium and mercury in Oreochromis aureus (Steindachner) during chronic exposure. Toxicol Environ Chem 44:101-112. https://doi. org/10.1080/02772249409358048 
Amin MM, Fawaz SB, Shalaby SI (2016) Suppression effect of vermicompost tea on onion white rot. Assiut J Agric Sci 47:8799. https://doi.org/10.21608/ajas.2016.2583

Amiri H, Ismaili A, Hosseinzadeh SR (2017) Influence of vermicompost fertilizer and water deficit stress on morphophysiological features of chickpea (Cicer arietinum L. cv. Karaj). Compost Sci Utili 25:152165. https://doi.org/10.1080/1065657X.2016.1249313

Amooaghaie R, Golmohammadi S (2017) Effect of vermicompost on growth, essential oil, and health of Thymus Vulgaris. Compost Sci Utili 25:166-177. https://doi.org/10.1080/1065657x.2016.1249314

Anastasi A, Varese GC, Voyron S, Scannerini S, Marchisio VF (2004) Characterization of fungal biodiversity in compost and vermicompost. Compost Sci Utili 12:185-191. https://doi.org/10. 1080/1065657x.2004.10702179

Arancon NQ, Edwards CA (2004) Vermicomposts can suppress plant pest and disease attacks. Biocycle

Arancon NQ, Edwards CA, Yardim EN, OliverT BRJ, Keeney G (2005) Suppression of two-spotted spidermite (Tetranychusurticae), mealy bugs (Pseudococcus sp.) and aphid (Myzus persicae) populations and damage by vermicomposts. Crop Prot 26:29-39. https://doi. org/10.1016/j.cropro.2006.03.013

Arancon NQ, Galvis PA, Edwards CA (2007a) Suppression of insect pest populations and damage to plants by vermicomposts. Bioresour Technol 96:1137-1142. https://doi.org/10.1016/j.biortech.2004.10.004

Arancon NQ, Edwards CA, Dick R, Dick L (2007b) Vermicompost tea production and plant growth impacts. Biocycle 48:51-52

Arancon NQ, Pant A, Radovich T, Hue NV, Potter JK, Converse CE (2012) Seed germination and seedling growth of tomato and lettuce as affected by vermicompost water extracts (teas). Hortic Sci 47: 1722-1728. https://doi.org/10.21273/hortsci.47.12.1722

Arancon N, Cleave JV, Hamasaki R, Nagata K, Felts J (2020) The influence of vermicompost water extracts on growth of plants propagated by cuttings. J Plant Nutr 43:176-185. https://doi.org/10.1080/ 01904167.2019.1659355

Argüello JA, Ledesma A, Núñez SB, Rodríguez CH, Goldfarb MD (2006) Vermicompost effects on bulbing dynamics, nonstructural carbohydrate content, yield, and quality of Rosado Paraguayo'garlic bulbs. Hortic Sci 41:589-592. https://doi.org/10. 21273/hortsci.41.3.589

Asciutto K, Rivera MC, Wright ER, Morisigue D, Lopez MV (2006) Effect of vermicompost on the growth and health of impatiens wallerana. Int J Exp Bot 75:115-123

Ashraf MS, Khan TA (2010) Integrated approach for the management of Meloidogyne javanica on eggplant using oil cakes and biocontrol agents. Arch Phytopathol Plant Protect 43:609-614. https://doi.org/ $10.1080 / 03235400801972434$

Aslam Z, Ahmad A (2020) Effects of Vermicompost, Vermi-tea and chemical fertilizer on morpho-physiological characteristics of maize (Zea mays L.) in Suleymanpasa District, Tekirdag of Turkey. J Innovat Sci 6:41-46. https://doi.org/10.17582/journal.jis/2020/6.1.41.46

Aslam Z, Ahmad A, Bellitürk K, Iqbal N, Idrees M, Rehman WU, Akbar G, Tariq M, Raza M, Riasat S, ur Rehman S (2020) Effects of vermicompost, vermi-tea and chemical fertilizer on morphophysiological characteristics of tomato (Solanum lycopersicum) in Suleymanpasa District, Tekirdag of Turkey. Pure Appl Biol 9:1920 1931. https://doi.org/10.19045/bspab.2020.90205

Atiyeh RM, Arancon NQ, Edwards CA, Metzger JD (2000a) Influence of earthworm-processed pig manure on the growth and yield of greenhouse tomatoes. Bioresour Technol 75:175-180. https://doi.org/10. 1016/s0960-8524(00)00064-x

Atiyeh RM, Subler S, Edwards CA, Bachman G, Metzger JD, Shuster W (2000b) Effects of vermicomposts and composts on plant growth in horticultural container media and soil. Pedobiol 445:579-590. https://doi.org/10.1078/s0031-4056(04)70073-6

Atiyeh RM, Lee SS, Edwards CA, Arancon NQ, Metzger J (2002a) The influence of humic acid derived from earthworm-processed organic waste on plant growth. Bioresour Technol 84:7-14. https://doi.org/ 10.1016/s0960-8524(02)00017-2

Atiyeh RM, Arancon NQ, Edwards CA, Metzger JD (2002b) The influence of earthworm-processed pig manure on the growth and productivity of marigolds. Bioresour Technol 81:103-108. https://doi. org/10.1016/s0960-8524(01)00122-5

Awad-Allah SF, Khalil MS (2019) Effects of vermicompost, vermicompost tea and a bacterial bioagent against Meloidogyne incognita on banana in Egypt. Pak J Nematol 37:25-33. https:// doi.org/10.18681/pjn.v37.i01.p25-33

Ayyobi H, Olfati JA, Peyvast GA (2014) The effects of cow manure vermicompost and municipal solid waste compost on peppermint (Mentha piperita L.) in torbat-e-jam and rasht regions of Iran. Int Recycl Org Waste Agric 3:147-153. https://doi.org/10.1007/ s40093-014-0077-8

Barman KL, Kalita RB, Jha DK (2013) Inductions of resistance in Brinjal (Solanum melongenae L.) by aqueous extract of vermicompost against Fusarium wilt. Inter J Plant Ani Environ Sci 3:141-148

Basco MJ, Bisen K, Keswani C, Singh HB (2017) Biological management of Fusarium wilt of tomato using biofortified vermicompost. Mycosp 8:467-483. https://doi.org/10.5943/mycosphere/8/3/8

Baum C, Eichler-Löbermann B, Hrynkiewicz K (2015) Impact of organic amendments on the suppression of Fusarium wilt. Springer Series Soil Biology In: Meghvansi MK, Varma A (Eds.), Organic Amendments and Soil Suppressiveness in Plant Disease Management. Springer, Cham, pp 353-362. https://doi.org/10. 1007/978-3-319-23075-7_16

Belda RM, Mendoza-Hernández D, Fornes F (2013) Nutrient-rich compost versus nutrient-poor vermicompost as growth media for ornamental-plant production. J Plant Nutr Soil Sci 176:827-835. https://doi.org/10.1002/jpln.201200325

Benhamou N, Chet I (1997) Cellular and molecular mechanisms involved in the interaction between Trichoderma harzianum and Pythium ultimum. Appl Environ Microbiol 63:2095-2099. https://doi.org/ 10.1128/aem.63.5.2095-2099.1997

Benitez E, Nogales R, Elvira C, Masciandaro G, Ceccanti B (1999) Enzymes activities as indicators of the stabilization of sewage sludges composting by Eisenia foetida. Bioresour Technol 67: 297-303. https://doi.org/10.1016/s0960-8524(98)00117-5

Benitez T, Ricon AM, Limon MC, Codon AC (2004) Biocontrol mechanisms of Trichoderma strains. Int Microbiol 7:249-260

Bhattacharjee G, Chaudhuri PS, Datta M (2001) Response of paddy (Var. TRC-87-251) crop on amendment of the field with different levels of vermicompost. Asian J Micro Biotechnol Environ Sci 3:191-196

Bisen K, Keswani C, Mishra S, Saxena A, Rakshit A, Singh HB (2015) Unrealized potential of seed biopriming for versatile agriculture. In nutrient use efficiency: from Basics to Advances (ed. Rakshit HB, Singh A), Springer India, pp 193-206. https://doi.org/10.1007/97881-322-2169-2 13

Bloem E, Albihn A, Elving J, Hermann L, Lehmann L, Sarvi M, Schaaf T, Schick J, Turtola E, Ylivainio K (2017) Contamination of organic nutrient sources with potentially toxic elements, antibiotics and pathogen microorganisms in relation to $\mathrm{P}$ fertilizer potential and treatment options for the production of sustainable fertilizers: a review. Sci Total Environ 607-608:225-242. https://doi.org/10.1016/ j.scitotenv.2017.06.274

Blouin M, Barrere J, Meyer N, Lartigue S, Barot S, Mathieu J (2019) Vermicompost significantly affects plant growth. A meta-analysis. Agron Sust Dev 39:34. https://doi.org/10.1007/s13593-019-0579-x

Brinton WF, Droffner M (1995) The control of plant pathogenic fungi by use of compost teas. Biodynam 197:12-15

Bunt AC (1988) Media and mixes for container-grown plants: a manual on the preparation and use of growing media for pot Plants, 2nd ed. Unwin Hyman, London https://doi.org/10.1007/978-94-011-7904-1_8

Cabanas-Echevarría M, Torres-García A, Díaz-Rodríguez B, Ardisana EF, Creme-Ramos Y (2005) Influence of three bioproducts of 
organic origin on the production of two banana clones (Musa spp AAB.) obtained by tissue cultures. Alimentaria 369:111-116

Cantisano A (1998) Compost teas. Organic Agricultural Advisors letter, Colfax

Cao W, Vaddella V, Biswas S, Perkins K, Clay C, Wu T, Zheng Y, Ndegwa P, Pandey P (2016) Assessing the changes in E. coli levels and nutrient dynamics during vermicomposting of food waste under lab and field scale conditions. Environ Sci Pollut Res 23:2319523202. https://doi.org/10.1007/s11356-016-7528-x

Cardoza YJ, Buhler WG (2012) Soil organic amendment impacts on corn resistance to Helicoverpa zea: constitutive or induced? Pedobiol 55: 343-347. https://doi.org/10.1016/j.pedobi.2012.08.002

Cayuela M, Millner P, Meyer S, Roig A (2008) Potential of olive mill waste and compost as biobased pesticides against weeds, fungi, and nematodes. Sci Total Environ 399:11-18. https://doi.org/10.1016/j. scitotenv.2008.03.031

Chaoui H, Edwards CA, Brickner M, Lee S, Arancon N (2002) Suppression of the plant diseases, Pythium (damping off), Rhizoctonia (root rot) and Verticillum (wilt) by vermicomposts. In: Proceedings of Brighton Crop Protection Conference Pests and Diseases, vol II, Brighton, UK, pp. 711-716

Chernin L, Ismailov Z, Haran S, Chet I (1995) Chitinolytic Enterobacter agglomerans antagonistic to fungal plant pathogens. Appl Environ Microbiol 61:1720-1726. https://doi.org/10.1128/aem.61.5.17201726.1995

Contreras-Ramos SM, Escamilla-Silva EM, Dendooven L (2005) Vermicomposting of biosolids with cow manure and oat straw. Biol Fertil Soils 41:190-198. https://doi.org/10.1007/s00374-0040821-8

Cotxarrera L, Trillas-Gay MI, Steinberg C, Alabouvette C (2002) Use of sewage sludge compost and Trichoderma asperellum isolates to suppress Fusarium wilt of tomato. Soil Biol Biochem 34:467-476. https://doi.org/10.1016/s0038-0717(01)00205-x

De Ceuster TJ, Hoitink HA (1999) Prospects for composts and biocontrol agents as substitutes for methyl bromide in biological control of plant diseases. Compost Sci Util 7:6-15. https://doi.org/10.1080/ $1065657 x .1999 .10701970$

De Corato U (2020) Disease-suppressive compost enhances natural soil suppressiveness against soil-borne plant pathogens: a critical review. Rhizosphere 5:100192. https://doi.org/10.1016/j.rhisph.2020. 100192

Devi TH, Das D (2016) Effect of organic amendments on root-knot nematode (Meloidogyne incognita) in cucumber. Pest Manag Horticul Ecosyst 22:176-181

Devi SH, Vijayalakshmi K, Jyotsna KP, Shaheen SK, Jyothi K, Rani MS (2009) Comparative assessment in enzyme activities and microbial populations during normal and vermicomposting. J Environ Biol 30: 1013-1017

Dia J, Becquer T, Rouiller JH, Reversat G, Bernhard-Reversat F, Nahmani J, Lavelle P (2004) Heavy metal accumulation by two earthworm species and its relationship tototal and DTPA extractable metals in soils. Soil Biol Biochem 36:91-98. https://doi.org/10. 1016/j.soilbio.2003.09.001

Dianez F, Santos M, Tello JC (2007) Suppressive effects of grape marc compost on phytopathogenic oomycetes. Arch Phytopathol Plant Protect 40:1-18. https://doi.org/10.1080/03235400500222339

Diver S (2001) Notes on compost teas: a 2001 supplement to the ATTRA publication 'compost teas for plant disease control. ATTRA publication, Fayetteville

Djonovic S, Vargas WA, Kolomiets MV, Horndeski M, Wiest A, Kenerley CM (2007) A proteinaceous elicitor Sm1 from the beneficial fungus Trichoderma virens is required for induced systemic resistance in maize. Plant Physiol 145:875-889

Doan TT, Henry-des-Tureaux T, Rumpel C, Janeau JL, Jouquet P (2015) Impact of compost, vermicompost and biochar on soil fertility, maize yield and soil erosion in northern Vietnam: a three year mesocosm experiment. Sci Total Environ 514:147-154. https:// doi.org/10.1016/j.scitotenv.2015.02.005

Dominguez J, Edwards CA, Subler S (1997) A comparison of vermicomposting and composting. BioCycle 38:57-59

Domínguez J, Aira M, Kolbe AR, Gómez-Brandón M, Pérez-Losada M (2019) Changes in the composition and function of bacterial communities during vermicomposting may explain beneficial properties of vermicompost. Sci Rep 4:1-1. https://doi.org/10.1038/s41598019-46018-w

dos Santos PT, Macêdo AG, da Silva J, Pinheiro JB, de Paula AM, Biscaia D, Busato JG (2020) Water-extractable fraction of vermicomposts enriched with Trichoderma enhances the growth of bell pepper and tomato as well as their tolerance against Meloidogyne incognita. Sci Hortic 272:109536. https://doi.org/10. 1016/j.scienta.2020.109536

Duffy B, Sarreal C, Ravva S, Stanker L (2004) Effect of molasses on regrowth of E. coli O157: H7 and Salmonella in compost teas. Compost Sci Util 12:93-96. https://doi.org/10.1080/1065657x. 2004.10702163

Edwards CA (2004) Earthworm ecology, 2nd edn. CRC Press, Boca Raton

Edwards CA, Arancon NQ (2004a) Vermicomposts suppress plant pest and disease attacks. Biocycle 45:51-55

Edwards CA, Arancon NQ (2004b) The use of earthworms in the breakdown of organic wastes to produce vermicomposts and animal feed protein. In: Edwards CA (ed) Earthworm Ecology, 2nd edn. CRC Press, Boca Raton, pp 345-438

Edwards CA, Dominguez J, Arancon NQ (2004) The influence of vermicomposts on plant growth and pest incidence. In: Shakir SH, Mikhail WZA (eds) Soil zoology for sustainable development in the 21st century. Self-Publisher Cairo, Egypt, pp 397-420

Edwards CA, Arancon NQ, Emerson E, Pulliman R (2007) Suppression of plant parasitic nematodes and arthropod pests with vermicompost tea. Biocycle:38-39

Edwards CA, Arancon NQ, Vasko-Bennett M, Askar A, Keeney G, Little B (2009) Suppression of green peach aphid (Myzus persicae) (Sulz.), citrus mealybug (Planococcus citri) (Risso), and two spotted spider mite (Tetranychus urticae) (Koch.) attacks on tomatoes and cucumbers by aqueous extracts from vermicomposts. Crop Prot 29: 80-93. https://doi.org/10.1016/j.cropro.2009.08.011

Edwards CA, Arancon NQ, Vasko-Bennett M, Askar A, Keeney G (2010) Effect of aqueous extracts from vermicomposts on attacks by cucumber beetles (Acalymna vittatum) (Fabr.) on cucumbers and tobacco hornworm (Manduca sexta) (L.) on tomatoes. Pedobiologia 53:141-148. https://doi.org/10.1016/j.pedobi.2009.08.002

Egwunatum A, Lane S (2009) Effects of compost age on the suppression of Armillaria mellea with green waste compost teas. Compost Sci Util 17:237-240. https://doi.org/10.1080/1065657x.2009.10702429

Elad Y, Shtienberg D (1994) Effect of compost water extracts on grey mould Botrytis cinerea. Crop Prot 13:109-114. https://doi.org/10. 1016/0261-2194(94)90160-0

El-Din AA, Hendawy SF (2010) Effect of dry yeast and compost tea on growth and oil content of Borago officinalis plant. Res J Agric Biol Sci 6:424-430

El-Haddad ME, Zayed MS, El-Sayed GA, Abd EL-Satar AM (2020) Efficiency of compost and vermicompost in supporting the growth and chemical constituents of salvia officinalis $\mathrm{L}$. cultivated in sand soil. Inter J Recy Organic Waste Agri 9:49-59

Elsharkawy MM, Shimizu M, Takahashi H, Ozaki K, Hyakumachi M (2013) Induction of systemic resistance against cucumber mosaic virus in Arabidopsis thaliana by Trichoderma asperellum SKT-1. Plant Pathol 29:193-200. https://doi.org/10.5423/ppj.si.07.2012. 0117

Erdal İ, Ekinci K (2020) Effects of composts and vermicomposts obtained from forced aerated and mechanically turned composting method on 
growth, mineral nutrition and nutrient uptake of wheat. J Plant Nutr 43:1343-1355. https://doi.org/10.1080/01904167.2020.1727506

Erhart E, Burian K, Hartl W, Stich K (1999) Suppression of Pythium ultimum by biowaste composts in relation to compost microbial biomass, activity and content of phenolic compounds. J Phytopathol 147:299-305. https://doi.org/10.1111/j.1439-0434. 1999.tb03834.x

Fornes F, Belda RM, Carrión C, Noguera V, García-Agustín P, Abad M (2007) Pre-conditioning ornamental plants to drought by means of saline water irrigation as related to salinity tolerance. Sci Hortic 113: 52-59. https://doi.org/10.1016/j.scienta.2007.01.008

Fracchia L, Dohrmann AB, Martinotti MG, Tebbe CC (2006) Bacterial diversity in a finished compost and vermicompost: differences revealed by cultivation-independent analyses of PCR-amplified 16S rRNA genes. Appl Microbiol Biotechnol 71:942-952. https://doi. org/10.1007/s00253-005-0228-y

Ganeshnauth V, Jaikishun S, Ansari AA, Homenauth O (2018) The effect of vermicompost and other fertilizers on the growth and productivity of pepper plants in Guyana. Autom Agric-Sec Food Suppl Future Gener 2018:14

Ganiger KS, Patil SR, Biradar PM (2020) Nutrient status of compost and vermicompost produced by different organic wastes. Asian J Exp Sci 34:19-24

García-Gómez A, Bernal MP, Roig A (2002) Ornamental plants growth in substrates using composts from agroindustrial wastes. Bioresour Technol 83:81-87. https://doi.org/10.1016/s0960-8524(01)00211-5

Ghasem S, Morteza AS, Maryam T (2014) Effect of organic fertilizers on cucumber (Cucumis sativus) yield. Int Agric Crop Sci 7:808

Gichaba VM, Muraya M, Ndukhu HO (2020) Effects of goat manurebased vermicompost on growth and yield of garlic (Allium sativum L.). Inter J Horticult Agricult Food Sci 4. https://doi.org/10.22161/ ijhaf.4.3.1

Gill JS, Walia SS (2014) Influence of FYM, brown manuring and nitrogen levels on direct seeded and transplanted rice (Oryza sativa L.) a review. Res Agr Env Sci 3:417-426. https://doi.org/10.20546/ ijcmas.2017.608.212

Gopal M, Gupta A, Sunil E, Thomas VG (2009) Amplification of plant beneficial microbial communities during conversion of coconut leaf substrate to vermicompost by Eudrilus sp. Curr Microbiol 59:15-20. https://doi.org/10.1007/s00284-009-9388-9

Gopalakrishnan S, Pande S, Sharma M, Humayun P, Kiran BK, Sandeep D, Vidya MS, Deepthi K, Rupela O (2011) Evaluation of actinomycete isolates obtained from herbal vermicompost for the biological control of Fusarium wilt of chickpea. Crop Prot 30:1070-1078. https://doi.org/10.1016/j.cropro.2011.03.006

Gowtham HG, Hariprasad P, Nayak SC, Niranjana SR (2016) Application of rhizobacteria antagonistic to Fusarium oxysporum f. sp. lycopersici for the management of Fusarium wilt in tomato. Rhizosphere 2:72-74. https://doi.org/10.1016/j.rhisph.2016.07.008

Grobe K (2003) California landscape contractor calls it compost tea time. BioCycle 44:26-27

Growing Solutions Incorporated (2012) Compost tea systems Growing Solutions Incorporated $2012 \mathrm{Feb} 27 \mathrm{http}$ ://www.growingsolutions. com/home/gs $2 /$ cpage $81 /$ Compost $\% 20$ Tea\%20Systems

Gupta SK, Tewari A, Srivastava R, Murthy RC, Chandra S (2005) Potential of Eisenia fetida for sustainable and efficient vermicomposting of fly ash. Water Air Soil Pollut 163:293-302. https://doi.org/10.1007/s11270-005-0722-y

Gutiérrez-Miceli FA, Santiago-Borraz J, Molina JAM, Nafate CC, AbudArchila M, Llaven MAO, Rincón-Rosales R, Dendooven L (2007) Vermicompost as a soil supplement to improve growth, yield and fruit quality of tomato (Lycopersicum esculentum). Bioresour Technol 98:2781-2786. https://doi.org/10.1016/j.biortech.2006.02. 032

Harel YM, Mehari ZH, Rav-David D, Elad Y (2014) Systemic resistance to gray mold induced in tomato by benzothiadiazole and
Trichoderma harzianum T39. Phytopathol 104:150-157. https:// doi.org/10.1094/phyto-02-13-0043-r

Hegazy MI, Hussein E, Salama A, Salama A (2015) Improving physicochemical and microbiological quality of compost tea using different treatments during extraction. Afr J Microbiol Res 13:763-770. https://oi.org/10.5897/ajmr2014.7324

Heinonen-Tanski H, Mohaibes M, Karinen P, Koivunen J (2006) Methods to reduce pathogen microorganisms in manure. Livest Sci 102:248-255. https://doi.org/10.1016/j.livsci.2006. 03.024

Hernandez T, Chocano C, Moreno JL, Garcia C (2014) Towards a more sustainable fertilization: combined use of compost and inorganic fertilization for tomato cultivation. Agric Ecosyst Environ 196: 178-184. https://doi.org/10.1016/j.agee.2014.07.006

Hoitink HA (1980) Composted bark, a lightweight growth medium with fungicidal properties. Plant Dis 64:142-147. https://doi.org/10. 1094/pd-64-142

Hoitink HAJ, Boehm MJ (1999) Biocontrol within the context of soil microbial communities: a substrate-dependent phenomenon. Annu Rev Phytopathol 37:427-446. https://doi.org/10.1146/annurev. phyto.37.1.427

Hoitink HA, Grebus ME (1997) Composts and control of plant diseases. In: Hayes MHB, Wilson WS (eds) Humic substances peats and sludges health and environmental aspects. Royal Society of Chemistry, Cambridge, pp 359-366. https://doi.org/10.1016/b9781-85573-805-8.50040-9

Hoitink HAJ, Boehm MJ, Hadar Y (1993) Mechanisms of suppression of soilborne plant pathogens in compost-amended substrates. In: Hoitink HAJ, Keener HM (eds) Science and engineering of composting: design, environmental, microbiological and utilization. Renaissance, Worthington (OH), pp 600-621

Hoitink H, Stone A, Grebus M (1996) Suppression of plant disease by composts. In: De BM (ed) The science of composting, vol 4. Chapman and Hall, London, pp 373-381. https://doi.org/10.1007/ 978-94-009-1569-5 35

Hoitink HA, Stone AG, Han DY (1997) Suppression of plant diseases by composts. Hortic Sci 32:184-187. https://doi.org/10.21273/hortsci. 32.2.184

Hoitink H, Madden L, Dorrance A (2006) Systemic resistance induced by Trichoderma spp.: interactions between the host, the pathogen, the biocontrol agent, and soil organic matter quality. Phytopathol 96: 186-199. https://doi.org/10.1094/phyto-96-0186

Horst LE, Locke J, Krause CR, McMahon RW, Madden LV, Hoitink HA (2005) Suppression of Botrytis Blight of Begonia by Trichoderma hamatum 382 in peat and compost-amended potting mixes. Plant Dis 89:1195-1200

Huang K, Li F, Wei Y, Fu X, Chen X (2014) Effects of earthworms on physicochemical properties and microbial profiles during vermicomposting of fresh fruit and vegetable wastes. Bioresour Technol 170:45-52. https://doi.org/10.1016/j.biortech.2014.07.058

Hunt DJ, Handoo ZA (2009) Taxonomy, identification and principal species. In: Perry RN, Moens M, Starr JL (eds) Root-knot nematodes. CABI, Wallingford, pp 55-97. https://doi.org/10.1079/ 9781845934927.0055

Hussain N, Abbasi T, Abbasi SA (2017) Enhancement in the productivity of ladies finger (Abelmoschus esculentus) with concomitant pest control by the vermicompost of the weed salvinia (Salvinia molesta, Mitchell). Inter J Recycl Organic Waste Agri 6:335-343. https://doi. org/10.1007/s40093-017-0181-7

Ingham ER (2005) The compost tea brewing manual. Soil Foodweb Incorporated, Corvallis

Ingram DT, Millner PD (2007) Factors affecting compost tea as a potential source of Escherichia coli and Salmonella on fresh produce. Food Prot 70:828-834. https://doi.org/10.4315/0362-028x-70.4.828

Islam MK, Yaseen T, Traversa A, Ben Kheder M, Brunetti G, Cocozza C (2016a) Effects of the main extraction parameters on chemical and 
microbial characteristics of compost tea. Waste Manag 52:62-68. https://doi.org/10.1016/j.wasman.2016.03.042

Islam MS, Hasan M, Rahman MM, Uddin MN, Kabir MH (2016b) Comparison between vermicompost and conventional aerobic compost produced from municipal organic solid waste used in amaranthus Viridis production. J Environ Sci Nat Res 9:43-49. https://doi.org/10.3329/jesnr.v9i2.32150

Istifadah N, Firman AR, Desiana MF (2020) Effectiveness of compost and microbial-enriched compost to suppress powdery mildew and early blight diseases in tomato. J Anim Plant Sci 30:377-383. https://doi.org/10.36899/japs.2020.2.0031

Jack AL, Rangarajan SA, Culman T, Sooksa-Nguan Thies JE (2011) Choice of organic amendments in tomato transplants has lasting effects on bacterial rhizosphere communities and crop performance in the field. Appl Soil Ecol 48:94-101. https://doi.org/10.1016/j. apsoil.2011.01.003

Jangra M, Sindhu S, Sonika RG, Batra VK (2019) Studies on efficacy of vermicompost for the management of Polyphagotarsonemus latus (Banks) (Acari: Tarsonemidae) infesting chilli (Capsicum annuum L.) in Haryana. Pharm Innovat J 8:86-89

Jayashree S, Rathinamala J, Lakshmanaperumalsamy P (2008) Biocomposting of leaf litters by Eudrilus eugeniae and its application on the growth of green gram (Vigna radiata (L) CO. 6). J Solid Waste Technol Manag 34:102-112

Jogaiah S, Abdelrahman M, Tran LS, Ito SI (2013) Characterization of rhizosphere fungi that mediate resistance in tomato against bacterial wilt disease. Exp Bot 64:3829-3842. https://doi.org/10.1093/jxb/ ert212

Joshi R, Singh J, Vig A (2015) Vermicompost as an effective organic fertilizer and biocontrol agent: effect on growth, yield and quality of plants. Rev Environ Sci Biotechnol 14:137-159. https://doi.org/10. 1007/s11157-014-9347-1

Joshi TN, Nepali DB, Sah R, Bhattarai T, Midmore DJ (2020) A comparison of composting and vermicomposting for the disposal of poultry waste. Anim Prod Sci 60:986-992. https://doi.org/10.1071/ an17177

Kadam AM, Oza GH, Nemade PD, Shankar HS (2008) Pathogen removal from municipal wastewater in constructed soil filter. Ecol Eng 33: 37-44. https://doi.org/10.1016/j.ecoleng.2007.12.001

Kamalraj R, Nandhivarman M, Thongni P, Pradheeps M, Poyyamoli G (2017) Utilization of Agrowastes for vermicomposting and its impact on growth and reproduction of selected earthworm species in Puducherry, India. Nat Environ Pollut Technol 1:16

Kannangara T, Utkhede RS, Paul JW, Punja ZK (2000) Effects of mesophilic and thermophilic composts on suppression of Fusarium root and stem rot of greenhouse cucumber. Can J Microbiol 46: 1021-1028. https://doi.org/10.1139/w00-082

Karimi H, Mokhtari M, Salehi F, Sojoudi S, Ebrahimi A (2017) Changes in microbial pathogen dynamics during vermicomposting mixture of cow manure-organic solid waste and cow manure-sewage sludge. Int J Recycl Org Waste Agric 6:57-61. https://doi.org/10.1007/ s40093-016-0152-4

Kashem MA, Sarker A, Hossain I, Islam MS (2015) Comparison of the effect of vermicompost and inorganic fertilizers on vegetative growth and fruit production of tomato (Solanum lycopersicum L.). Open J Soil Sci 5:53-58. https://doi.org/10.4236/ojss.2015.52006

Kaur P, Bhardwaj M, Babbar I (2015) Effect of vermicompost and vermiwash on growth of vegetables. Res J AnimVet Fish Sci 3:9-12

Keswani C, Mishra S, Sarma BK, Singh SP, Singh HB (2014) Unraveling the efficient applications of secondary metabolites of various Trichoderma spp. Appl Microbiol Biotechnol 98:533-544. https:// doi.org/10.1007/s00253-013-5344-5

Ketterer N, Fisher B, Weltzien HC (1992) Biological control of Botrytis cinerea on grapevine by compost extracts and their microorganisms in pure culture. In: Verhoeff K, Malathrakis NE, Williamson B (eds)
Recent advances in Botrytis research. Proceedings of the 10th International Botrytis symposium, Hera kl ion, pp 179-186

Khalil I, El-Mghrabia K (2010) Biological control of Fusarium dry rot and other potato tuber diseases using Pseudomonas fluorescens and Enterobacter cloacae. Biol Control 53:280-284. https://doi.org/10. 1016/j.biocontrol.2010.01.010

Khattiyaphutthimet N, Chuasavathi T, Iwai CB (2020) Nutrient dynamic of vermicompost tea after adding molasses and oxygen. Inter $\mathrm{J}$ Environ Rural Dev 10:6-9

Kilani-Feki O, Khedher SB, Dammak M, Kamoun A, JabnounKhiareddine H, Daami-Remadi M, Tounsi S (2016) Improvement of antifungal metabolites production by Bacillus subtilis V26 for biocontrol of tomato postharvest disease. Biol Control 95:73-82. https://doi.org/10.1016/j.biocontrol.2016.01.005

Kim MJ, Shim CK, Kim YK, Hong SJ, Park JH, Han EJ, Kim JH, Kim SC (2015) Effect of aerated compost tea on the growth promotion of lettuce, soybean, and sweet corn in organic cultivation. Plant Pathol 31:259-268. https://doi.org/10.5423/ppj.oa.02.2015.0024

Kmet'ová M, Kováčik P (2014) The impact of vermicompost application on the yield parameters of maize (Zea mays L.) observed in selected phenological growth stages (BBCH-scale). Acta Fytotech Zootech 17:100-108. https://doi.org/10.15414/afz.2014.17.04.100-108

Kone' SB, Dionne A, Tweddell RJ, Antoun H, Avis TJ (2010) Suppressive effect of non-aerated compost teas on foliar fungal pathogens of tomato. Biol Control 52:167-173. https://doi.org/10. 1016/j.biocontrol.2009.10.018

Kumar R, Sharma S, Prasad R (2013) Yield, nutrient uptake and quality of stevia as affected by organic sources of nutrient. Commun Soil Sci Plant Nutr 44:3137-3149. https://doi.org/10.1080/00103624. 2013.832285

Kuter GA, Nelson EB, Hoitink HAJ, Madden LV (1983) Fungal populations in container media amended with composted hardwood bark suppressive and conducive to Rhizoctonia dampingoff. Phytopathol 73:1450-1456. https://doi.org/10.1094/phyto-73-1450

Kwok O, Fahy P, Hoitink HA, Kuter G (1987) Interactions between bacteria and Trichoderma hamatum in suppression of rhizoctonia damping-off in bark compost media. Phytopathology 77:12061212. https://doi.org/10.1094/phyto-77-1206

Lazcano C, Gómez-Brandón M, Domínguez J (2008) Comparison of the effectiveness of composting and vermicomposting for the biological stabilization of cattle manure. Chemosphere 72:1013-1019. https:// doi.org/10.1016/j.chemosphere.2008.04.016

Lefrancq M, Imfeld G, Payraudeau S, Millet M (2013) Kresoxim methyl deposition, drift and runoff in a vineyard catchment. Sci Total Environ 442:503-508. https://doi.org/10.1016/j.scitotenv.2012.09. 082

Lievens B, Vaes K, Coosemans J, Ryckeboer J (2001) Systemic resistance induced in cucumber against Pythium root rot by source separated household waste and yard trimmings composts. Com Sci Utili 9:221-229. https://doi.org/10.1080/1065657x.2001.10702039

Lim SL, Wu TY, Lim PN, Shak KP (2015) The use of vermicompost in organic farming: overview, effects on soil and economics. J Sci Food Agric 95:1143-1156. https://doi.org/10.1002/jsfa.6849

Litterick A, Wood M (2009) The use of composts and compost extracts in plant disease control. In: Walters D (ed) Disease control in crops: biological and environmentally friendly approaches. WileyBlackwell, Oxford, pp 93-121. https://doi.org/10.1002/ 9781444312157.ch5

Little AG, Cardoza YJ (2011) Host plant effects on generalist and specialist lepidopterous cabbage pests modulated by organic soil amendment. Pedobiologia 54:353-359. https://doi.org/10.1016/j. pedobi.2011.08.004

Liu D, Han WE, Zhang YA, Jiang Y (2019) Evaluation of vermicompost and extracts on tomato root-knot nematode. Bangla Bot 48:845-851

Lumsden RD, Locke JC, Adkins ST, Walter JF, Ridout CJ (1992) Isolation and localization of the antibiotic gliotoxin produced by 
Gliocladium virens from alginate prill in soil and soilless media. Phytopathol 82:230-235. https://doi.org/10.1094/phyto-82-230

Mahaffee W, Scheuerell S (2006) Compost teas: alternative approaches to the biological control of plant diseases. In: Bailey M, Lilley A, Timms-Wilson T, Spencer-Phillips P (eds) Microbial Ecology of Aerial Plant Surfaces. CAB International, London, pp 165-179. https://doi.org/10.1079/9781845930615.0165

Mahmud M, Abdullah R, Yaacob JS (2018) Effect of vermicompost amendment on nutritional status of sandy loam soil, growth performance, and yield of pineapple (Ananas comosus var. MD2) under field conditions. Agronomy 8:183. https://doi.org/10.3390/ agronomy 8090183

Makode PM (2015) Effect of vermicompost on the growth of Indian orange, Citrus reticulates with reference to its quality and quantity. Biosci Biotech Res Comm 8:217-220

Malone RW, Ahuja LR, Ma L, DonWauchope R, Ma Q, Rojas KW (2004) Application of the root zone water quality model (RZWQM) to pesticide fate and transport: an overview. Pest Manag Sci 60:205-221. https://doi.org/10.1002/ps.789

Manandhar T, Yami KD (2008) Biological control of foot rot disease of rice using fermented products of compost and vermicompost. Sci World 6:52-55. https://doi.org/10.3126/sw.v6i6.2634

Martin CC (2014) Potential of compost tea for suppressing plant diseases. CAB Reviews 9:1-38. https://doi.org/10.1079/pavsnnr20149032

Martin CC, Brathwaite RA (2012) Compost and compost tea: principles and prospects as substrates and soil-borne disease management strategies in soil-less vegetable production. Biol Agric Hortic 28:1-33. https://doi.org/10.1080/01448765.2012.671516

Martin CC, Dorinvil W, Brathwaite RA, Ramsubhag A (2012) Effects and relationships of compost type, aeration and brewing time on compost tea properties, efficacy against Pythium ultimum, phytotoxicity and potential as a nutrient amendment for seedling production. Biol Agric Hortic 28:185-205. https://doi.org/10.1080/ 01448765.2012.727667

Mas-Carrió E, Dini-Andreote F, Brossi MJ, Salles J, Olff H (2018) Organic amendment under increasing agricultural intensification: effects on soil bacterial communities and plant productivity. Front Microbiol 9:2612. https://doi.org/10.3389/fmicb.2018.02612

Matz C, Kjelleberg S, Givskov M (2007) Biofilms as refuge against predation. In: Kjelleberg S, Givskov M (eds) The biofilm mode of life: mechanisms and adaptations. Horizon Bioscience, Norwich, pp 195-213

Mendoza-Hernández D, Fornes F, Belda RM (2014) Compost and vermicompost of horticultural waste as substrates for cutting rooting and growth of rosemary. Sci Hortic 178:192-202. https://doi.org/10. 1016/j.scienta.2014.08.024

Mengesha W, Powell S, Evans K, Barry K (2017) Suppression of potato bacterial wilt with non-aerated compost tea and factors which influence efficacy. In Science Protecting Plant Health, Brisbane, p 51

Mishra S, Singh A, Keswani C, Saxena A, Sarma BK, Singh HB (2015) Harnessing plant-microbe interactions for enhanced protection against phytopathogens. In: Arora NK (ed) In Plant Microbes Symbiosis: Applied Facets. Springer, India, pp 111-125. https:// doi.org/10.1007/978-81-322-2068-8 5

Mishra S, Sipes BS, Tian M, Wang KH (2016) Vermicompost tea mediated plant resistance against root-knot nematodes, Meloidogyne spp. J Nematol 48:352-353

Mishra S, Wang KH, Sipes BS, Tian M (2017) Suppression of root-knot nematode by vermicompost tea prepared from different curing ages of vermicompost. Plant Dis 101:734-737. https://doi.org/10.1094/ pdis-07-16-1068-re

Mishra S, Wang KH, Sipes BS, Tian M (2018) Induction of host-plant resistance in cucumber by vermicompost tea against root-knot nematode. Nematropica 48:164-171
Mitchell A (1997) Production of Eisenia fetida and vermicompost from feed-lot cattle manure. Soil Biol Biochem 29:763-766. https://doi. org/10.1016/s0038-0717(96)00022-3

Mokhtar MM, El-Mougy NS (2008) Bio-compost application for controlling soilborne plant pathogens- a review. Populat 4:154-162

Morra L, Palumbo AD, Bilotto M, Ovieno P, Picascia S (1998) Soil solarization: organic fertilization and grafting contribute to build an integrated production system in a tomato-zucchini sequence. Colture-Protette 27:63-70

Munnoli PM, Teixeira da Silva JA, Bhosle S (2010) Dynamics of the soil - earthworm - plant relationship: a review. Dynam Soil Dynam Plant 4:1-21

Munroe G (2007) Manual of on-farm vermicomposting and vermiculture. Publication of Organic Agriculture Centre of Canada, Nova Scotia

Mylavarapu RS, Zinati GM (2009) Improvement of soil properties using compost for optimum parsley production in sandy soils. Sci Hortic 120:426-430. https://doi.org/10.1016/j.scienta.2008.11.038

Naidu Y, Meon S, Kadir J, Siddiqui Y (2010) Microbial starter for the enhancement of biological activity of compost tea. Int J Agric Biol 12:51-56

Nakasone AK, Bettiol W, de Souza RM (1999) The effect of water extracts of organic matter on plant pathogens. Summa Phytopathol 25: 330-335

Nasreen A, Mustafa G, Ashfaq M (2003) Selectivity of some insecticides to Chrysoperla carnea (Stephen) (Neuroptera: Chrysopidae) in laboratory. Pak J Biol Sci 6:536-538. https://doi.org/10.3923/pjbs. 2003.536.538

Nath G, Singh K (2012) Combination of vermiwash and biopesticides against aphid (Lipaphis erysimi) infestation and their effect on growth and yield of mustard (Brassica compestris). Dyn Soil Dyn Plant 6:96-102

Nath G, Singh DK, Singh K (2011) Productivity enhancement and nematode management through vermicompost and biopesticides in brinjal (Solanum melogena L.). World Appl Sci J 12:404-412

Nelson E, Kuter G, Hoitink H (1983) Effects of fungal antagonists and compost age on suppression of Rhizoctonia damping-off in container media amended with composted hardwood bark. Phytopathol 73: 1457-1462. https://doi.org/10.1094/phyto-73-1457

NOSB (2004) Compost tea task force final report. National Organic Standards Board

Oka Y (2010) Mechanisms of nematode suppression by organic amendments - a review. Appl Soil Ecol 44:101-115. https://doi.org/10. 1016/j.apsoil.2009.11.003

Olle M (2016) The effect of vermicompost based growth substrates on tomato growth. Agraarteadus: J Agricul Sci Akadeemilise Põllumajanduse Seltsi väljaanne

Palmer AK, Evans KJ, Brown J, Ross T, Metcalf DA, Palmer AK (2010) Potential for growth of $E$. coli in aerobic compost extract. Compost Sci Utili 18:152-161. https://doi.org/10.1080/1065657x.2010. 10736951

Pandya U, Maheshwari DK, Saraf M (2014) Assessment of ecological diversity of rhizobacterial communities in vermicompost and analysis of their potential to improve plant growth. Biologi 69:968-976. https://doi.org/10.2478/s11756-014-0406-4

Pane C, Spaccini R, Piccolo A, Scala F, Bonanomi G (2011) Compost amendments enhance peat suppressiveness to Pythium ultimum, Rhizoctonia solani and Sclerotinia minor. Biol Control 56:115124. https://doi.org/10.1016/j.biocontrol.2010.10.002

Pane C, Celano G, Villecco D, Zaccardelli M (2012) Control of Botrytis cinerea, Alternaria alternata and Pyrenochaeta lycopersici on tomato with whey compost-tea applications. Crop Prot 38:80-86. https://doi.org/10.1016/j.cropro.2012.03.012

Pant A (2011) Vermicompost tea: effect on pak choi ( Brassica rap acv.Bonsai,Chinensis group) growth and yield, phytonutrient content and soil biological properties. $\mathrm{PhD}$ dissertation, University of Hawaii, Honolulu, Hawaii 
Pant A, Radovich TJ, Hue NV, Talcott ST, Krenek KA (2009) Vermicompost extracts influence growth, mineral nutrients, phytonutrients and antioxidant activity in pak choi (Brassica rapa $\mathrm{cv}$. Bonsai, Chinensis group) grown under vermicompost and chemical fertilizer. J Sci Food Agric 89:2383-2392. https://doi.org/10. $1002 /$ jsfa. 3732

Pantelides IS, Tjamos SE, Striglis IA, Chatzipavlidis I, Paplomatas EJ (2009) Mode of action of a non-pathogenic Fusarium oxysporum strain against Verticillium dahliae using real time QPCR analysis and biomarker transformation. Biol Control 50:30-36. https://doi. org/10.1016/j.biocontrol.2009.01.010

Passarini KC, Pereira MA, de Brito Farias TM, Calarge FA, Santana CC (2014) Assessment of the viability and sustainability of an integrated waste management system for the city of Campinas (Brazil), by means of ecological cost accounting. J Clean Prod 65:479-488. https://doi.org/10.1016/j.jclepro.2013.08.037

Pathma J, Sakthivel N (2012) Microbial diversity of vermicompost bacteria that exhibit useful agricultural traits and waste management potential. Springer Plus 1:26. https://doi.org/10.1186/2193-1801-1-26

Pathma J, Sakthivel N (2013) Molecular and functional characterization of bacteria isolated from straw and goat manure based vermicompost. Appl Soil Ecol 70:33-47. https://doi.org/10.1016/j. apsoil.2013.03.011

Pathma J, Sakthivel N (2014) Microbial and functional diversity of vermicompost bacteria. In Bacterial Diversity in Sustainable Agriculture Springer, Cham, pp 205-225. https://doi.org/10.1007/ 978-3-319-05936-5_9

Patriquin DG, Baines D, Abboud A (1995) Diseases, pests and soil fertility. In: Cook HF, Lee HC (eds) Soil management in sustainable agriculture. Wye College, Wye, pp 161-174

Pattnaik S, Reddy MV (2010) Assessment of municipal solid waste management in Puducherry (Pondicherry), India. Resour Conserv Recycl 54:512-520. https://doi.org/10.1016/j.resconrec.2009.10.008

Peerzada SH, Bhat KA, Viswanath HS (2020) Studies on management of late blight (Phytophthora infestans (Mont) de Bary) of potato using organic soil amendments. Int J Curr Microbiol App Sci 9:20932099. https://doi.org/10.20546/ijcmas.2020.902.237

Pieterse CM, Zamioudis C, Berendsen RL, Weller DM, Van Wees SC, Bakker PA (2014) Induced systemic resistance by beneficial microbes. Annu Rev Phytopathol 52:347-375. https://doi.org/10. 1146/annurev-phyto-082712-102340

Priyanka M, Pooja S, Tripathi NN (2014) Evaluation of plant extracts against Fusarium oxysporum f. sp. lycopersici, wilt pathogen of tomato. Res J Microbiol 9:129-134

Punja ZK, Rodriguez G, Tirajoh A (2016) Effects of Bacillus subtilis strain QST 713 and storage temperatures on post-harvest disease development on greenhouse tomatoes. Crop Prot 84:98-104. https://doi.org/10.1016/j.cropro.2016.02.011

Ragab Mona MM, Abada KA, Abd-El-Moneim ML, Abo-Shosha Yosra Z (2015) Effect of different mixtures of some bioagents and Rhizobium phaseoli on bean damping-off under field condition. Int J Sci Eng Res 6:1009-1106

Ramesh P (2000) Effects of vermicomposts and vermicomposting on damage by sucking pests to ground nut (Arachis hypogea). Ind $\mathbf{J}$ Agric Sci 70:334

Rao KR, Rao PA, Rao KT (2001) Influence of fertilizers and manures on the population of coccinellid beetles and spiders in groundnut ecosystem. Annu Plant Prot Sci 9:43-46

Rao MS, Kamalnath M, Umamaheswari R, Rajinikanth R, Prabu P, Priti K, Grace GN, Chaya MK, Gopalakrishnan C (2017) Bacillus subtilis IIHR BS-2 enriched vermicompost controls root knot nematode and soft rot disease complex in carrot. Sci Hortic 218:56-62. https://doi. org/10.1016/j.scienta.2017.01.051

Ravindran B, Contreras-Ramos SM, Sekaran G (2015) Changes in earthworm gut associated enzymes and microbial diversity on the treatment of fermented tannery waste using epigeic earthworm Eudrilus eugeniae. Ecol Eng 74:394-401. https://doi.org/10.1016/j.ecoleng. 2014.10.014

Ravindran B, Wong JW, Selvam A, Sekaran G (2016) Influence of microbial diversity and plant growth hormones in compost and vermicompost from fermented tannery waste. Bioresour Technol 217:200-204. https://doi.org/10.1016/j.biortech.2016.03.032

Ravindran B, Lee SR, Chang SW, Nguyen DD, Chung WJ, Balasubramanian B, Mupambwa HA, Arasu MV, Al-Dhabi NA, Sekaran G (2019) Positive effects of compost and vermicompost produced from tannery waste-animal fleshing on the growth and yield of commercial crop-tomato (Lycopersicon esculentum L.) plant. J Environ Manag 234:154-158. https://doi.org/10.1016/j. jenvman.2018.12.100

Ray DK, Mueller ND, West PC, Foley JA (2013) Yield trends are insufficient to double global crop production by 2050. PLoS One 8: e66428. https://doi.org/10.1371/journal.pone.0066428

Rekha GS, Kaleena PK, Elumalai D, Srikumaran MP, Maheswari VN (2018) Effects of vermicompost and plant growth enhancers on the exo-morphological features of Capsicum annum (Linn.) Hepper. Inter Recycl Org Waste Agricul 7:83-88. https://doi.org/10.1007/ s40093-017-0191-5

Renčo M, Kovácik P (2015) Assessment of the nematicidal potential of vermicompost, vermicompost tea, and urea application on the potato-cyst nematodes Globodera rostochiensis and Globodera pallida. J Plant Protec Res 55:187-192. https://doi.org/10.1515/jppr-20150025

Renčo M, Sasanelli N, Kováčik P (2011) The effect of soil compost treatments on potato cyst nematodes Globodera rostochiensis and Globodera pallida. Helminthol 48:184-194

Rivera MC, Wright ER, Lopez MV, Garda D, Barrague MY (2004) Promotion of growth and control of damping-off (Rhizoctonia solani) of greenhouse tomatoes amended with vermicompost. Int J Exp Bot (Phyton) 54:229-235

Roberts DP, Lumsden RD (1990) Effect of extracellular metabolites from Gliocladium virens on germination of sporangia and mycelial growth of Pythium ultimum. Phytopathol. 80:461-465. https://doi. org/10.1094/phyto-80-461

Rodríguez-Kábana R (1986) Organic and inorganic nitrogen amendments to soil as nematode suppressants. J Nematol 18:129-134

Sahni S, Sarma BK, Singh DP, Singh HB, Singh KP (2008a) Vermicompost enhances performance of plant growth-promoting rhizobacteria in Cicer arietinum rhizosphere against Sclerotium rolfsii. Crop Prot 27:369-376. https://doi.org/10.1016/j.cropro. 2007.07.001

Sahni S, Sarma BK, Singh KP (2008b) Management of Sclerotium rolfsii with integration of nonconventional chemicals, vermicompost and Pseudomonas syringae. World J Microbiol Biotechnol 24:517-522. https://doi.org/10.1007/s11274-007-9502-8

Samadhiya H, Chauhan PS, Gupta RB, Agrawal OP (2014) Effect of vermiwash and vermicompost of Eudrilus Eugeniae on the growth and development of leaves and stem of Brinjal plant (Solanum Melongena). Octa J Environ Res 1:3

Sanchez-Monedero MA, Roig A, Paredes C, Bernal MP (2001) Nitrogen transformation during organic waste composting by the Rutgers system and its effects on $\mathrm{pH}, \mathrm{EC}$ and maturity of the composting mixtures. Bioresour Technol 78:301-308. https://doi.org/10.1016/ s0960-8524(01)00031-1

Sang MK, Kim KD (2011) Biocontrol activity and primed systemic resistance by compost water extracts against anthracnoses of pepper and cucumber. Phytopathology 101:732-740. https://doi.org/10. 1094/phyto-10-10-0287

Sarma BK, Singh P, Pandey SK, Singh HB (2010) Vermicompost as modulator of plant growth and disease suppression. Dyn Soil Dyn Plant 4:58-66

Scheuerell S (2002) Compost teas and compost amended container for plant disease control [Ph.D.]. Oregon State University, Corvallis 
Scheuerell S (2003) Understanding how compost tea can control disease. BioCycle 44:20-25

Scheuerell SJ, Mahaffee WF (2002) Compost tea principals and prospects for plant disease control. Compost Sci Util 10:313-338. https://doi. org/10.1080/1065657x.2002.10702095

Scheuerell SJ, Mahaffee WF (2004) Compost tea as a container medium drench for suppressing seedling damping-off caused by Pythium ultimum. Phytopathol 94:1156-1163. https://doi.org/10.1094/ phyto.2004.94.11.1156

Scheuerell SJ, Mahaffee WF (2006) Variability associated with suppression of gray mold (Botrytis cinerea) on Geranium by foliar applications of nonaerated and aerated compost teas. Plant Dis 90:12011208. https://doi.org/10.1094/pd-90-1201

Scheuerell SJ, Sullivan DM, Mahaffee WF (2005) Suppression of seedling damping-off caused by Pythium ultimum, P. irregulare, and Rhizoctonia solani in container media amended with diverse range of Pacific Northwest compost sources. Phytopathol 95:306-315. https://doi.org/10.1094/phyto-95-0306

Schmidt O, Doubre BM, Ryder MH, Killman K (1997) Population dynamics of Pseudomonas corrugata 2140R LUX8 in earthworm food and in earthworm cast. Soil Biol Biochem 29:523-528. https://doi. org/10.1016/s0038-0717(96)00036-3

Seddigh S, Kiani L (2018) Evaluation of different types of compost tea to control rose powdery mildew (Sphaerotheca pannosa var. rosae). Inter J pest Manag 64:178-184. https://doi.org/10.1080/09670874. 2017.1361050

Serra-Wittling C, Houot S, Alabouvette C (1996) Increased soil suppressiveness to Fusarium wilt of flax after addition of municipal solid waste compost. Soil Biol Biochem 28:1207-1214. https://doi.org/ 10.1016/0038-0717(96)00126-5

Siddiqui Y, Meon S, Ismail R, Rahmani M, Ali A (2008) Bio-efficiency of compost extracts on the wet rot incidence, morphological and physiological growth of okra Abelmoschus esculentus [(L.) Moench]. Sci Hortic 117:9-14. https://doi.org/10.1016/j.scienta. 2008.03.008

Siddiqui Y, Meon S, Ismail R, Rahmani M (2009) Bio-potential of compost tea from agro-waste to suppress Choanephora cucurbitarum $\mathrm{L}$. the causal pathogen of wet rot of okra. Biol Control 49:38-44. https://doi.org/10.1016/j.biocontrol.2008.11.008

Simsek-Ersahin Y, Haktanir K, Yanar Y (2009) Vermicompost from agricultural wastes suppress Rhizoctonia Solani Kuhn in cucumber seedlings. J Plant Dis Prot 116:182-188. https://doi.org/10.1007/ bf03356308

Singh S, Mallick MA (2020) Agronomic impact of vermicompost, FYM and mixed compost on the growth of two medicinal plants- Bacopa Monnieri L. and Centella Asiatica L. Plant Archives 20:497-500

Singh A, Singh GS (2017) Vermicomposting: a sustainable tool for environmental equilibria. Environ Qual Manag 27:23-40. https://doi. org/10.1002/tqem.21509

Singh UP, Maurya S, Singh DP (2003) Antifungal activity and induced resistance in pea by aqueous extract of vermicompost and for control of powdery mildew of pea and balsam. J Plant Dis Prot 110:544 553

Singh R, Sharma RR, Kumar S, Gupta RK, Patil RT (2008) Vermicompost substitution influences growth, physiological disorders, fruit yield and quality of strawberry (Fragaria 9 ananassa Duch.) Biores. Technol 99:8507-8511. https://doi.org/10.1016/j. biortech.2008.03.034

Singh R, Gupta RK, Patil RT, Sharma RR, Asrey R, Kumar A, Jangra KK (2010) Sequential foliar application of vermicompost leachates improves marketable fruit yield and quality of strawberry (Fragaria $\times$ ananassa Duch.). Sci Hortic 124:34-39. https://doi.org/10.1016/j. scienta.2009.12.002

Singh RP, Singh P, Araujo ASF, Ibrahim MH, Sulaiman O (2011) Management of urban solid waste: vermicomposting a sustainable option. Resour Conserv Recycl 55:719-729. https://doi.org/10. 1016/j.resconrec.2011.02.005

Sinha RK, Herat S, Bharambe G, Brahambhatt A (2010) Vermistabilization of sewage sludge (biosolids) by earthworms: converting a potential biohazard destined for landfill disposal into a pathogen-free, nutritive and safe biofertilizer for farms. Waste Manag Res 28:872-881. https://doi.org/10.1177/ $0734242 \times 09342147$

Soobhany N, Mohee R, Garg VK (2017a) Acomparative analysis of composts and vermicomposts derived from municipal solid waste for the growth and yield of green bean (Phaseolus vulgaris). Environ Sci Pollut Res 24:11228-11239. https://doi.org/10.1007/s11356017-8774-2

Soobhany N, Gunasee S, Rago YP, Joyram H, Raghoo P, Mohee R, Garg VK (2017b) Spectroscopic, thermogravimetric and structural characterization analyses for comparing Municipal Solid Waste composts and vermicomposts stability and maturity. Bioresour Technol 236:11-19. https://doi.org/10.1016/j.biortech.2017.03.161

Srivastava R, Khalid A, Singh US, Sharma AK (2010) Evaluation of arbuscular mycorrhizal fungus, fluorescent Pseudomonas and Trichoderma harzianum formulation against Fusarium oxysporum f. sp. lycopersici for the management of tomato wilt. Biol Control 53:24-31. https://doi.org/10.1016/j.biocontrol.2009.11.012

St. Martin CC, Brathwaite RA (2012) Compost and compost tea: principles and prospects as substrates and soil-borne disease management strategies in soil-less vegetable production. Biol Agri Horticul iFirst article, 1-33. https://doi.org/10.1080/01448765.2012.671516

Stewart-Wade SM (2020) Efficacy of organic amendments used in containerized plant production: part 1-compost-based amendments. Sci Hortic 266:108856. https://doi.org/10.1016/j.scienta.2019.108856

Suarez-Estrella F, Vargas-Garcia C, Lopez MJ, Capel C, Moreno J (2007) Antagonistic activity of bacteria and fungi from horticultural compost against Fusarium oxysporum f. sp. melonis. Crop Prot 26:4653. https://doi.org/10.1016/j.cropro.2006.04.003

Subler S, Edwards C, Metzger J (1998) Comparing vermicomposts and composts. BioCycle 39:63-65

Suthar S (2007) Nutrient changes and biodynamics of epigeic earthworm Perionyx excavatus (Perrier) during recycling of some agriculture wastes. Bioresour Technol 98:1608-1614. https://doi.org/10.1016/j. biortech.2006.06.001

Swathi P, Rao KT, Rao PA (1998) Studies on control of root-knot nematode Meloidogyne incognita in tobacco miniseries. Tob Res 1:26-30

Szczech M (1999) Supressiveness of vermicompost against Fusarium wilt of tomato. J Phytopathol 147:155-161. https://doi.org/10. 1111/j.1439-0434.1999.tb03822.x

Szczech MM, Smolinska U (2001) Comparison of suppressiveness of vermicomposts produced from animal manures and sewage sludge against Phytophthora nicotianae Breda de Haan var. nicotianae. J Phytopathol 149:77-82. https://doi.org/10.1046/j.1439-0434.2001. 00586.x

Tejada M, Gonzalez JL, Hernandez MT, Garcia C (2008) Agricultural use of leachates obtained from two different vermicomposting processes. Bioresour Technol 99:6228-6232. https://doi.org/10.1016/j. biortech.2007.12.031

Termorshuizen AJ, van Rijn E, van der Gaag DJ, Alabouvette C, Chen Y, Lagerlof J, Malandrakis AA, Paplomatas EJ, Ramert B, Ryckeboer J (2006) Suppressiveness of 18 composts against seven pathosystems: variability in pathogen response. Soil Biol Biochem 38:2461-2477. https://doi.org/10.1016/j.soilbio.2006.03.002

Tian X, Zheng Y (2013) Compost teas and reused nutrient solution suppress plant pathogens in vitro. Hortic Sci 48:510-512. https://doi. org/10.21273/hortsci.48.4.510

Tiunov AV, Scheu S (2000) Microfungal communities in soil litter and casts of Lumbricus terrestris (Lumbricidae): a laboratory experiment. Appl Soil Ecol 14:17-26. https://doi.org/10.1016/s09291393(99)00050-5 
Tognetti C, Laos F, Mazzarino MJ, Hernandez MT (2005) Composting vs. vermicomposting: a comparison of end product quality. Compost Sci Utili 13:6-13. https://doi.org/10.1080/1065657x. 2005.10702212

Tomati U, Grappelli A, Galli E (1988) The hormone like effect of earthworm casts on plant growth. Biol Fertil Soils 5:288-294. https://doi. org $/ 10.1007 / \mathrm{bf00262133}$

Turk MA, Assaf TA, Hameed KM, Al-Tawaha AM (2006) Significance of mycorrhizae. World J Agric Sci 2:16-20

Van Beneden S, Roobroeck D, Franta SC, De Neve S, Boeckx P, Hofte M (2010) Microbial populations involved in the suppression of Rhizoctonia solani AG1-1B by lignin incorporation in soil. Soil Biol Biochem 42:1268-1274. https://doi.org/10.1016/j.soilbio. 2010.04.007

Villar MC, Beloso MC, Acea MJ, Cabaneiro A, González-Prieto SJ, Carballas M, Díaz-Raviña M, Carballas T (1993) Physical and chemical characterization of four composted urban refuses. Bioresour Technol 45:105-113. https://doi.org/10.1016/09608524(93)90098-V

Vinale F, Flematti G, Sivasithamparam K, Lorito M, Marra R, Skelton BW, Ghisalberti EL (2009) Harzianic acid, an antifungal and plant growth promoting metabolite from Trichoderma harzianum. J Nat Prod 72:2032-2035. https://doi.org/10.1021/np900548p

Viterbo A, Horwitz BA (2010) Mycoparasitism. In: Borkovich KA, Ebbole DJ (eds) In: Cellular and Molecular Biology of Filamentous Fungi. Amer Soci Microbiol, Washington, pp 676693. https://doi.org/10.1128/9781555816636.ch42

Vivas A, Moreno B, Garcia-Rodriguez S, Benitez E (2009) Assessing the impact of composting and vermicomposting on bacterial community size and structure, and microbial functional diversity of an olive-mill waste. Bioresour Technol 100:1319-1326. https://doi.org/10.1016/ j.biortech.2008.08.014

Wang KH, Radovich T, Pant A, Cheng Z (2014) Integration of cover crops and vermicompost tea for soil and plant health management in a short term vegetable cropping system. Appl Soil Ecol 82:26-37. https://doi.org/10.1016/j.apsoil.2014.05.003

Weltzien HC (1990) The use of composted materials for leaf disease suppression in field crops monograph Br. Crop Prot Count 45: $115-120$

Weltzien HC (1991) Biocontrol of foliar fungal disease with compost extracts, pp 430-450. https://doi.org/10.1007/978-1-4612-3168-4 22

Yami K, Shrestha A (2005) Selective utilization of organic substrates during vermicomposting and the study of microflora. J Nepal Biotechnol Assoc 2:23-26

Yardim EN, Arancon NQ, Edwards CA, Oliver TJ, Byrne RJ (2006) Suppression of tomato hornworm (Manduca quinquemaculata) and cucumber beetles (Acalymma vittatum and Diabotrica undecimpunctata) populations and damage by vermicomposts. Pedobiologia 50:23-29. https://doi.org/10.1016/j.pedobi.2010.01.002

Yatoo AM, Rasool S, Ali S, Majid S, Rehman MU, Ali MN, Eachkoti R, Rasool S, Rashid SM, Farooq S (2020) Vermicomposting: an ecofriendly approach for recycling/management of organic wastes. In: In :Bioremediation and Biotechnology. Springer, Cham, pp 167 187. https://doi.org/10.1007/978-3-030-35691-0_8

You X, Tojo M, Ching S, Wang KH (2018) Effects of vermicompost water extract prepared from bamboo and kudzu against Meloidogyne incognita and Rotylenchulus reniformis. Soc Nematol 50:569-578. https://doi.org/10.21307/jofnem-2018-054

You X, Kimura N, Okura T, Murakami S, Okano R, Shimogami Y, Matsumura A, Tokumoto H, Ogata Y, Tojo M (2019) Suppressive effects of vermicomposted-bamboo powder on cucumber dampingoff. Jpn Agric Res Q 53:13-19. https://doi.org/10.6090/jarq.53.13

Yousefi AA, Sadeghi M (2014) Effect of vermicompost and urea chemical fertilizers on yield and yield components of wheat (Triticum aestivum) in the field condition. Int J Agric Crop Sci 7:1227-1230

Zaller JG (2006) Foliar spraying of vermicompost extracts: effects on fruit quality and indications of late-blight suppression of fieldgrown tomatoes. Biol Agric Hortic 24:165-180. https://doi.org/10. 1080/01448765.2006.9755017

Zandvakili OR, Barker AV, Hashemi M, Etemadi F (2019) Biomass and nutrient concentration of lettuce grown with organic fertilizers. J Plant Nutr 42:444-457. https://doi.org/10.1080/01904167.2019. 1567778

Zarei M, Abadi VA, Moridi A (2018) Comparison of vermiwash and vermicompost tea properties produced from different organic beds under greenhouse conditions. Inter J Recy Org Waste Agric 7:2532. https://doi.org/10.1007/s40093-017-0186-2

Zhang X, Sa R, Gao J, Wang C, Liu D, Zhang Y (2020) Preventive effect of vermicompost against cucumber Fusarium wilt and improvement of cucumber growth and soil properties. Int J Agric Biol 23:515-521

Zhu F, Jingtao H, Xue S, Chuan W, Qiongli W, Hartley W (2017) Vermicompost and gypsum amendments improve aggregate formation in bauxite residue. Land Degrad Dev 28:2109-2120. https://doi. org/10.1002/ldr.2737

Zucco MA, Walters SA, Chong SK, Klubek BP, Masabni JG (2015) Effect of soil type and vermicompost applications on tomato growth. Int J Recycl Org Waste Agric 4:135-141. https://doi.org/10.1007/ s40093-015-0093-3

Publisher's note Springer Nature remains neutral with regard to jurisdictional claims in published maps and institutional affiliations. 